\title{
Effects of rumen-protected methionine, lysine, and histidine on lactation performance of dairy cows
}

\author{
F. Giallongo, ${ }^{*}$ M. T. Harper, ${ }^{*}$ J. Oh, ${ }^{*}$ J. C. Lopes, ${ }^{*}$ H. Lapierre,† R. A. Patton,‡ C. Parys,§ I. Shinzato,\# \\ and A. N. Hristov*1 \\ *Department of Animal Science, The Pennsylvania State University, University Park 16802 \\ †Sherbrooke Research and Development Centre, Agriculture and Agri-Food Canada, Sherbrooke, QC, Canada J1M 0C8 \\ ‡Nittany Dairy Nutrition Inc., Mifflinburg, PA 17844 \\ §Evonik Nutrition \& Care GmbH, 63457 Hanau, Germany \\ \#Ajinomoto Co., Inc., Tokyo, Japan 104
}

\section{ABSTRACT}

The objective of this study was to evaluate the effects of supplementing a metabolizable protein (MP)-deficient diet with rumen-protected (RP) Met, Lys, and His, individually or combined, on the performance of lactating dairy cows. The experiment was a 9 -wk randomized complete block design with 72 Holstein cows. Following a 2-wk covariate period, cows were blocked by days in milk, milk yield, and parity, and randomly assigned to 1 of the following 6 treatments: (1) MPadequate diet $[\mathrm{MPA} ;+243 \mathrm{~g} / \mathrm{d}$ MP balance, according to the National Research Council (2001) requirements]; (2) MP-deficient diet (MPD; $-54 \mathrm{~g} / \mathrm{d}$ MP balance); (3) MPD supplemented with RPMet (MPDM); (4) MPD supplemented with RPLys (MPDL); (5) MPD supplemented with RPHis (MPDH); and (6) MPD supplemented with RPMet, RPLys, and RPHis (MPDMLH). Dry matter intake (DMI), yields of milk and milk components (fat, protein, lactose) and energy-corrected milk (ECM), feed and ECM feed efficiencies, and milk and plasma urea $\mathrm{N}$ were decreased by MPD, compared with MPA. Supplementation of the MPD diet with RPLys increased milk protein content and plasma glucose concentration and tended to increase milk urea N. Addition of RPHis tended to increase DMI, increased milk protein concentration, and numerically increased yields of milk fat, protein, and ECM. In addition to the trends for increased DMI and milk fat content, and higher milk protein concentration, supplementation of the 3 RP AA also increased yields of milk fat, protein, and ECM and ECM feed efficiency. Relative to MPA, milk $\mathrm{N}$ efficiency tended to be increased by MPD. Concentrations of plasma essential AA (except Met and Thr) were decreased by MPD compared with MPA. Supplementation of RPMet, RPLys, and RPHis

Received December 26, 2015.

Accepted February 27, 2016.

${ }^{1}$ Corresponding author: anh13@psu.edu increased plasma Met (except for MPDM), Lys, and His concentrations, respectively. Cows fed MPD had lower blood hemoglobin concentration and numerically higher plasma ghrelin than cows fed MPA. Concentration of total saturated fatty acids in milk fat were or tended to be higher for MPD compared with MPA and MPDMLH, respectively. Concentration of total polyunsaturated and yield of milk odd- and branched-chain fatty acids were or tended to be decreased by MPD compared with MPA. Overall, the results of this study confirm our previous data and suggest that His stimulates DMI and the combination of the 3 RP AA (Met, Lys, and His) has the potential to improve milk and milk component yields in dairy cows fed MP-deficient diets.

Key words: metabolizable protein, rumen-protected methionine, rumen-protected lysine, rumen-protected histidine, dairy cow

\section{INTRODUCTION}

In commercial dairy farms, lactating cows convert about 20 to $35 \%$ of dietary CP into milk and excrete the remaining $\mathrm{N}$ in manure, causing farm management and environmental issues (Chase et al., 2012). Increased environmental concerns and regulations, along with the need to sustainably feed the world's growing population (OECD/FAO, 2015), is leading to a trend for decreasing the protein content of dairy diets. Feeding dietary protein levels below current NRC (2001) recommendations is the most efficient way to enhance $\mathrm{N}$ utilization for milk protein production in dairy cows (Huhtanen and Hristov, 2009). However, decreasing dietary protein concentration and intake below the actual requirements of the cow always carries the risk of decreasing DMI, milk production, or milk protein yield (MPY), or a combination of these. Supplementation of low-protein diets with specific AA is a promising strategy to counteract the potential negative effect of overall MP deficiency on dairy cows productivity (Hristov and Gial- 
longo, 2014). Methionine and Lys have been recognized as the 2 most limiting AA for milk protein production in typical corn-alfalfa forage-based diets (NRC, 2001). However, the observed production responses to their supplementation in cows fed low-protein diets have been, in most cases, small and inconsistent (Arriola Apelo et al., 2014a; Sinclair et al., 2014), suggesting that other EAA may also be limiting.

In a series of studies with lactating cows fed proteinfree diets, Virtanen (1967) found that, of all EAA, His was the least synthesized by rumen bacteria, and plasma His decreased more than any other plasma AA relative to the control cows. Histidine infusion experiments in North Europe (Kim et al., 1999, 2000; Vanhatalo et al., 1999; Huhtanen et al., 2002) showed the importance of His for milk and milk protein synthesis in dairy cows fed grass silage-based diets. These studies, together with the consistent observations of lower His content in ruminal microbial protein compared with milk protein and most feedstuffs (NRC, 2001), indicated that His may be a limiting AA for lactating cows fed diets deficient in MP (particularly when microbial protein provides most of the MP; Lee et al., 2012a; Patton et al., 2014).

Indeed, His has been shown to be a limiting AA and to exert a stimulatory effect on DMI in dairy cows fed low-protein typical North American diets based on corn and alfalfa silages. Lee et al. (2012a) observed trends for increased DMI and milk yield with addition of rumen-protected (RP) His to a 13\% MP-deficient diet balanced for Met and Lys. Similarly, Giallongo et al. (2015a) reported an increase in DMI and milk protein content and MPY by supplementing RPHis in combination with RPMet to a 5\% MP-deficient diet. In these studies, however, RPHis was supplemented with at least another limiting AA.

Therefore, the objective of the present experiment was to determine the effects of supplementing a MPdeficient diet with RPMet, RPLys, and RPHis, or the combination of the 3 RP AA, on DMI, milk production and composition, $\mathrm{N}$ efficiency, and concentration of plasma AA and certain metabolites and hormones in dairy cows. We hypothesized that supplementation of a MP-deficient diet with (1) RPHis may improve DMI, milk yield, and MPY; (2) RPMet, RPLys, or both may increase milk protein content and MPY; (3) a combination of the 3 RP AA (Met, Lys, His) may further increase milk yield and MPY.

\section{MATERIALS AND METHODS}

The Animal Care and Use Committee at The Pennsylvania State University reviewed and approved all procedures used in this experiment.

\section{Animals and Experimental Design}

The experiment was a complete randomized block design and was carried out in 2 phases at The Pennsylvania State University's Dairy Teaching and Research Center. Cows were housed in a sand-bedded freestall barn equipped with the Calan Broadbent Feeding System (American Calan Inc., Northwood, NH) for individual daily feeding and measurement of feed intake. Cows had free access to drinking water. All cows were trained to use the Calan feeding system before the beginning of each phase of the experiment. Phase 1 (October to December 2014) involved 36 lactating Holstein cows (20 primiparous and 16 multiparous) averaging $( \pm \mathrm{SD}): 40.8 \pm 6.80 \mathrm{~kg} / \mathrm{d}$ of milk yield, 132 \pm 30 DIM, $2 \pm 1.3$ lactations, and $611 \pm 81 \mathrm{~kg}$ of $\mathrm{BW}$ at the beginning of the experiment (i.e., first day of the covariate period). Phase 2 (January to March 2015) involved another 36 cows (16 primiparous and 20 multiparous) averaging ( $\pm \mathrm{SD}): 39.8 \pm 6.67 \mathrm{~kg} / \mathrm{d}$ of milk yield, $98 \pm 40.7$ DIM, $2 \pm 1.0$ lactations, and 545 $\pm 65.3 \mathrm{~kg}$ of $\mathrm{BW}$ at the beginning of the experiment. Each phase of the experiment lasted 9 wk, including a 2 -wk covariate period followed by a 7 -wk experimental period (which included $2 \mathrm{wk}$ for diet adaptation and 5 wk for data and samples collection). During the covariate period, cows were fed the main herd diet, which had similar ingredient composition to the experimental diets (i.e., Table 1; \% of DM): 40.1 corn silage, 20.1 alfalfa haylage, 7.7 ground and 4.3 cracked corn, 8.9 candy by-product meal, 6.7 solvent-extracted canola meal, 5 molasses, 3.7 heat-treated whole soybeans, 3.2 mineral/vitamin premix, and 0.3 Optigen (Alltech Inc., Nicholasville, KY). The covariate diet contained (\% of $\mathrm{DM})$ : $14.9 \mathrm{CP}, 31.1 \mathrm{NDF}, 43.8 \mathrm{NFC}$; and $1.50 \mathrm{Mcal} /$ $\mathrm{kg}$ of $\mathrm{NE}_{\mathrm{L}}$. The control, MP-adequate $\operatorname{diet}(\mathrm{MPA})$ was formulated to meet or exceed the NRC (2001) nutrient requirements for lactating Holstein cows with $650 \mathrm{~kg}$ of BW, $27 \mathrm{~kg} / \mathrm{d}$ of DMI, $42.5 \mathrm{~kg} / \mathrm{d}$ of milk yield, and with $3.80 \%$ milk fat and $3.20 \%$ true protein (Table 1). The MP-deficient diet (MPD) was formulated to be about 5 to $10 \%$ deficient in MP, based on NRC (2001), at actual DMI, milk production, and BW data of the cows during the 2-wk covariate period.

Because of the higher CP and NDF and lower NFC contents of the corn and alfalfa silages, and lower MP requirements of the cows during phase 2 of the experiment, the composition of the basal diets was slightly modified in phase 2 (Table 1 ). In particular, the inclusion of ground corn was increased and that of the candy by-product meal, whole soybeans, canola meal, and SoyPLUS was decreased.

In both phases of the experiment, following the covariate period, cows were blocked based on DIM, milk 
Table 1. Ingredient and chemical composition of the basal diets fed in the experiment

\begin{tabular}{|c|c|c|c|c|}
\hline \multirow[b]{3}{*}{ Item } & \multicolumn{4}{|c|}{$\operatorname{Diet}^{1}$} \\
\hline & \multicolumn{2}{|c|}{ Phase $1^{2}$} & \multicolumn{2}{|c|}{ Phase $2^{2}$} \\
\hline & MPA & MPD & MPA & MPD \\
\hline \multicolumn{5}{|l|}{ Ingredient, $\%$ of DM } \\
\hline Corn silage ${ }^{3}$ & 42.0 & 42.0 & 42.0 & 42.0 \\
\hline Alfalfa haylage $^{4}$ & 21.0 & 21.0 & 21.0 & 21.0 \\
\hline Cottonseed hulls ${ }^{5}$ & 4.0 & 4.0 & 4.0 & 4.0 \\
\hline Ground corn ${ }^{6}$ & 1.5 & 6.5 & 6.3 & 11.5 \\
\hline Candy by-product meal ${ }^{7}$ & 5.5 & 5.5 & 3.5 & 3.5 \\
\hline Heat-treated whole soybeans ${ }^{8}$ & 4.5 & 4.5 & 4.0 & 4.0 \\
\hline Solvent-extracted canola meal ${ }^{9}$ & 8.5 & 8.5 & 6.5 & 6.5 \\
\hline SoyPLUS ${ }^{10}$ & 6.0 & 1.0 & 5.7 & 0.5 \\
\hline Molasses $^{11}$ & 4.0 & 4.0 & 4.0 & 4.0 \\
\hline Mineral/vitamin premix $^{12}$ & 3.0 & 3.0 & 3.0 & 3.0 \\
\hline \multicolumn{5}{|l|}{ Composition, \% of DM } \\
\hline $\mathrm{CP}^{13,14}$ & 16.8 & 14.8 & 16.1 & 14.1 \\
\hline $\mathrm{RDP}^{15}$ & 10.2 & 9.6 & 9.6 & 9.1 \\
\hline RUP $^{15}$ & 6.7 & 5.2 & 6.5 & 4.9 \\
\hline $\mathrm{NDF}^{13}$ & 32.4 & 31.8 & 34.0 & 33.4 \\
\hline $\mathrm{ADF}^{13}$ & 22.7 & 22.6 & 24.2 & 24.0 \\
\hline $\mathrm{NFC}^{15}$ & 40.5 & 43.2 & 39.6 & 42.4 \\
\hline Starch $^{13}$ & 19.0 & 22.0 & 20.1 & 23.2 \\
\hline Fat $^{13}$ & 4.65 & 4.53 & 4.46 & 4.34 \\
\hline $\mathrm{NE}_{\mathrm{L}},{ }^{15} \mathrm{Mcal} / \mathrm{kg}$ & 1.53 & 1.52 & 1.50 & 1.47 \\
\hline $\mathrm{NE}_{\mathrm{L}}$ intake ${ }^{15} \mathrm{Mcal} / \mathrm{d}$ & 44.4 & 42.2 & 43.4 & 41.3 \\
\hline $\mathrm{NE}_{\mathrm{L}}$ balance, ${ }^{15} \mathrm{Mcal} / \mathrm{d}$ & 2.60 & 4.00 & 3.00 & 6.00 \\
\hline $\mathrm{Ash}^{13}$ & 7.28 & 7.04 & 7.29 & 7.04 \\
\hline $\mathrm{Ca}^{13}$ & 0.98 & 0.96 & 0.99 & 0.97 \\
\hline $\mathrm{P}^{13}$ & 0.41 & 0.39 & 0.39 & 0.37 \\
\hline
\end{tabular}

${ }^{1} \mathrm{MPA}=\mathrm{MP}$-adequate diet; $\mathrm{MPD}=\mathrm{MP}$-deficient diet. Four additional diets were fed in this experiment: MPDM = MPD supplemented with $30 \mathrm{~g} /$ cow per day of rumen-protected (RP) Met (Mepron; Evonik Nutrition \& Care GmbH, Hanau, Germany); MPDL = MPD supplemented with $130 \mathrm{~g} / \mathrm{cow}$ per day of RPLys (AjiPro-L; Ajinomoto Co., Inc., Tokyo, Japan); MPDH = MPD supplemented with $120 \mathrm{~g} / \mathrm{cow}$ per day of RPHis (experimental product; Ajinomoto Co., Inc.); and MPDMLH = MPD supplemented with $30 \mathrm{~g}$ of RPMet, $130 \mathrm{~g}$ of RPLys, and $120 \mathrm{~g}$ of RPHis/cow per day.

${ }^{2}$ The experiment was conducted in 2 phases (phase 1: October to December 2014; phase 2: January to March 2015; for details see Materials and Methods section).

${ }^{3}$ Corn silage was 41.1 and $31.8 \% \mathrm{DM}$ and contained (DM basis) 6.3 and $6.9 \% \mathrm{CP}, 52.3$ and $48.4 \% \mathrm{NFC}, 39.0$ and $35.0 \%$ starch, and 34.9 and $38.7 \%$ NDF (phase 1 and 2, respectively).

${ }^{4}$ Alfalfa haylage was 42.6 and $52.9 \%$ DM and contained (DM basis) 21.0 and $21.5 \%$ CP, 24.8 and $21.2 \%$ NFC, and 42.7 and $46.2 \%$ NDF (phase 1 and 2, respectively).

${ }^{5}$ Cottonseed hulls contained (DM basis) $8.6 \% \mathrm{CP}$ (average of phase 1 and 2).

${ }^{6}$ Ground corn contained (DM basis) $7.5 \%$ CP (average of phase 1 and 2).

${ }^{7}$ Candy by-product meal (Graybill Processing, Elizabethtown, PA) contained (DM basis) $14.6 \%$ CP and $27.9 \%$ NDF (average of phase 1 and 2).

${ }^{8}$ Whole soybeans contained (DM basis) $37.9 \% \mathrm{CP}$ (average of phase 1 and 2).

${ }^{9}$ Canola meal contained (DM basis) $40.6 \% \mathrm{CP}$ (average of phase 1 and 2 ).

${ }^{10}$ SoyPLUS (West Central Cooperative, Ralston, IA) contained (DM basis) 47.3\% CP (average of phase 1 and 2).

${ }^{11}$ Molasses (Westway Feed Products, Tomball, TX) contained (DM basis) 3.9\% CP and 66\% total sugar.

${ }^{12}$ The mineral/vitamin premix (Cargill Animal Nutrition, Cargill Inc., Roaring Spring, PA) contained (\%, as-is basis) trace mineral mix, 0.86; $\mathrm{MgO}(56 \% \mathrm{Mg}), 8.0 ; \mathrm{NaCl}, 6.4$; vitamin ADE premix (Cargill Animal Nutrition, Cargill Inc.), 0.48; limestone, 37.2; selenium premix (Cargill Animal Nutrition, Cargill Inc.), 0.07; and dry corn distillers grains with solubles, 46.7; Ca, 14.1\%; P, 0.39\%; Mg, 4.60\%; K, 0.45\%; S, 0.38\%; Se, $6.67 \mathrm{mg} /$ $\mathrm{kg} ; \mathrm{Cu}, 358 \mathrm{mg} / \mathrm{kg}$; Zn, 1,085 mg/kg; Fe, $188 \mathrm{mg} / \mathrm{kg}$, vitamin A, 262,656 IU/kg; vitamin D, 65,559 IU/kg; and vitamin E, 1,974 IU/kg.

${ }^{13}$ Values calculated using the chemical analysis (Cumberland Valley Analytical Services Inc., Maugansville, $\mathrm{MD}$ ) of individual feed ingredients of the diet.

${ }^{14} \mathrm{CP}$ content of the MPDM, MPDL, MPDH, and MPDMLH diets was 14.8 and $14.1 \%, 14.9$ and $14.2 \%, 14.9$ and $14.2 \%, 15.1$ and $14.4 \%$ (phase 1 and 2, respectively).

${ }^{15}$ Estimated based on NRC (2001). 
yield, and parity into 6 blocks of 6 cows per block, and cows within block were randomly assigned to 1 of 6 experimental diets: (1) MPA, providing $+243 \mathrm{~g} / \mathrm{d}$ of MP requirements according to NRC (2001); (2) MPD (-54 $\mathrm{g} / \mathrm{d}$ of MP requirements); (3) MPD supplemented with RPMet $[30 \mathrm{~g} /$ cow per day of Mepron (Evonik Nutrition \& Care GmbH, Hanau, Germany); MPDM]; (4) MPD supplemented with RPLys [130 g/cow per day of AjiPro-L (Ajinomoto Co., Inc., Tokyo, Japan); MPDL]; (5) MPD supplemented with RPHis [120 g/cow per day of an experimental RP L-His product (Ajinomoto Co., Inc.); MPDH]; and (6) MPD supplemented with 30 $\mathrm{g}$ of RPMet, $130 \mathrm{~g}$ of RPLys, and $120 \mathrm{~g}$ of RPHis/ cow per day (MPDMLH). The 2 basal experimental diets were mixed using a Rissler model 1050 TMR mixer (I.H. Rissler Mfg. LLC, Mohnton, PA) and fed as TMR once daily $(0630 \mathrm{~h})$ ad libitum to ensure about 5 to $10 \%$ refusals. The RP AA supplements (RPMet, RPLys, and RPHis) were fed top-dressed and mixed with a small portion of the TMR immediately after the MPD diet was delivered to the cows. All cows were milked twice daily (0600 and $1800 \mathrm{~h}$ ) and received rbST (Posilac, Elanco Co., Greenfield, IN; $500 \mathrm{mg} / \mathrm{cow}$, i.m.) at 14-d intervals.

Ruminal degradability of the 3 RP AA (i.e., RPMet, RPLys, and RPHis) was determined in an in situ subexperiment as described by Lee et al. (2012a), except 3 ruminally cannulated cows (average \pm SD: $35 \pm 7.5$ $\mathrm{kg} / \mathrm{d}$ of milk yield, $24 \pm 1.7 \mathrm{~kg} / \mathrm{d}$ of DMI, $229 \pm 68$ DIM, and $696 \pm 42 \mathrm{~kg}$ of BW) were used for the incubation. The cannulated cows were fed the covariate diet as described above. Five grams of each individual RP AA per bag was incubated in the rumen of the cows for $0,1,3,6,12$, and $24 \mathrm{~h}$. Bags were inserted sequentially at specified time points and removed simultaneously from the rumen. Aliquots of the original RPMet, RPLys, and RPHis products and residues of each in situ bag were analyzed for Met, Lys, and His content, respectively, at the University of MissouriColumbia Agricultural Experiment Station Chemical Laboratory (Columbia, MO). Based on the estimated (NRC, 2001) ruminal escape of Met, Lys, and His (77, 88 , and $92 \%$, respectively) and intestinal digestibility of the AA provided by the manufacturers $(90,62$, and $20 \%$, respectively), bioavailability of AA from RP AA was estimated at 69,54 , and $18 \%$ for RPMet, RPLys, and RPHis, respectively. A rumen passage rate of $8 \% / \mathrm{h}$ was used to estimate ruminal escape of the $3 \mathrm{RP}$ AA. Thus, the supplemental RP AA provided 17.8, 27.6, and $9.3 \mathrm{~g} /$ cow per day of digestible Met (dMet), Lys (dLys), and His (dHis), respectively (Table 2). The supplementation doses of RPMet, RPLys, and RPHis were determined assuming dMet and dLys and dHis requirements of 2.2 and $6.6 \%$ (Schwab et al., 2005) and
$2.2 \%$ (Lee et al., 2012a) of MP requirements, respectively.

\section{Sampling and Measurements}

Individual feed intake, milk yield, and BW (AfiFarm 3.04E scale system; S.A.E. Afikim, Rehovot, Israel) of the cows were recorded daily during the entire experiment. Samples of the TMR and refusals from each diet were collected twice weekly and composited (equal weight basis) by week and treatment. Samples of individual forages and concentrates were collected weekly. Forages were composited by phase, whereas one composite sample for each concentrate was prepared for the entire experiment. All samples were stored at $-20^{\circ} \mathrm{C}$, dried in a forced-air oven (at $55^{\circ} \mathrm{C}$ for $72 \mathrm{~h}$ ) for $\mathrm{DM}$ determination, and grounded with a Wiley Mill (1-mm screen; Thomas Scientific, Swedesboro, NJ) for later analysis. Daily DMI was calculated from the as-fed feed intake using the DM percentage of the weekly TMR and refusal composite samples. Composite samples of forages and concentrates were submitted to Cumberland Valley Analytical Services (Maugansville, MD) for wet chemistry analyses of $\mathrm{CP}, \mathrm{NDF}, \mathrm{ADF}$, starch, ash, $\mathrm{Ca}, \mathrm{P}$, and estimated $\mathrm{NFC}$ and $\mathrm{NE}_{\mathrm{L}}$. Details of the procedures can be found at http://www.foragelab.com/Resources/Lab-Procedures, accessed November 23, 2015. Feeds were also analyzed for AA by Evonik Nutrition \& Care $\mathrm{GmbH}$ following standard procedures (AOAC International, 1995; European Commission, 2009). Performic acid oxidation was used for Met and Cys analysis. The $\mathrm{CP}, \mathrm{NDF}, \mathrm{ADF}$, starch, ash, $\mathrm{Ca}$, and $\mathrm{P}$ content of the diets (Table 1) were calculated from the wet chemistry analysis of the feed ingredients and their inclusion in the TMR. Concentrations of RDP, RUP, $\mathrm{NFC}, \mathrm{NE}_{\mathrm{L}}$, and $\mathrm{NE}_{\mathrm{L}}$ and protein fraction balances, and AA supply from the diet were estimated using NRC (2001) based on the analyzed composition of the feed ingredients and actual DMI, milk yield and composition, and $\mathrm{BW}$ of the cows during the experiment. The analyzed $\mathrm{N}$ content and estimated bioavailability data of each individual RP AA were included in the calculation of the CP content of the diets and protein fraction balances. The AA balances for dMet, dLys, and dHis were calculated as the sum of the digestible flow (NRC, 2001) and the digestible supply for RP AA when present minus assumed requirements (as described above).

Two sets of blood samples were collected from the tail vein or artery into Vacutainer plastic $\mathrm{K}_{2}$ EDTA tubes (Becton Dickinson, Franklin Lakes, NJ) at 6 and $11 \mathrm{~h}$ after feeding on d 7 during wk 2 of the covariate period and wk 4 and 6 of the experimental period. Blood plasma was separated after centrifugation $(1,500 \times g$ for 15 $\min$ at $4^{\circ} \mathrm{C}$ ) and a $2-\mathrm{mL}$ aliquot was treated with $1 \mathrm{~N}$ 
$\mathrm{HCl}$ and phenylmethylsulfonyl fluoride and stored in a plastic tube at $-20^{\circ} \mathrm{C}$ until analyzed for active ghrelin (RIA kit GHRA-88HK; EMD Millipore Corp., Billerica, MA). The remaining plasma was stored in separate plastic tubes at $-20^{\circ} \mathrm{C}$ for later analysis. Aliquots of the plasma samples were composited (equal-volume basis) per cow and week, and then analyzed for urea N (Stanbio Urea Nitrogen Kit 580; Stanbio Laboratory Inc., Boerne, TX), glucose (Stanbio Glucose kit 1070; Stanbio Laboratory Inc.), insulin (RIA kit PI-12K; EMD Millipore Corp.), and creatinine (QuantiChrom Creatinine assay kit, DICT-500; BioAssays Systems, Hayward, CA). Plasma samples (wk 2 of the covariate period and experimental wk 6 only) were also analyzed for AA profile as described above for feed ingredients by Evonik Nutrition \& Care GmbH. An additional set of blood samples was collected at $6 \mathrm{~h}$ after feeding (as described above) and analyzed the same day for hemoglobin concentration by using an hematology analyzer (Hemavet 950FS; Drew Scientific Inc., Oxford, CT).

Milk samples were collected in tubes with 2-bromo2-nitropropane-1,3-diol preservative during wk 2 of the covariate period and wk 4, 5, and 6 of the experimental period from 2 consecutive milkings (p.m. and a.m.), and analyzed separately for fat, true protein, TS, lactose, and MUN (method 972.16, AOAC International, 2012) using infrared spectroscopy (MilkoScan FT+, Foss, Eden Prairie, MN) by Dairy One Cooperative Inc. (Ithaca, NY). Milk composition data were weighted for the corresponding p.m. and a.m. milk yield, averaged by sampling week, and the average values were used in the statistical analysis. A separate set of milk samples

Table 2. Protein fractions and AA balance ${ }^{1}$ in dairy cows fed diets adequate or deficient in MP and supplemented with rumen-protected (RP) AA

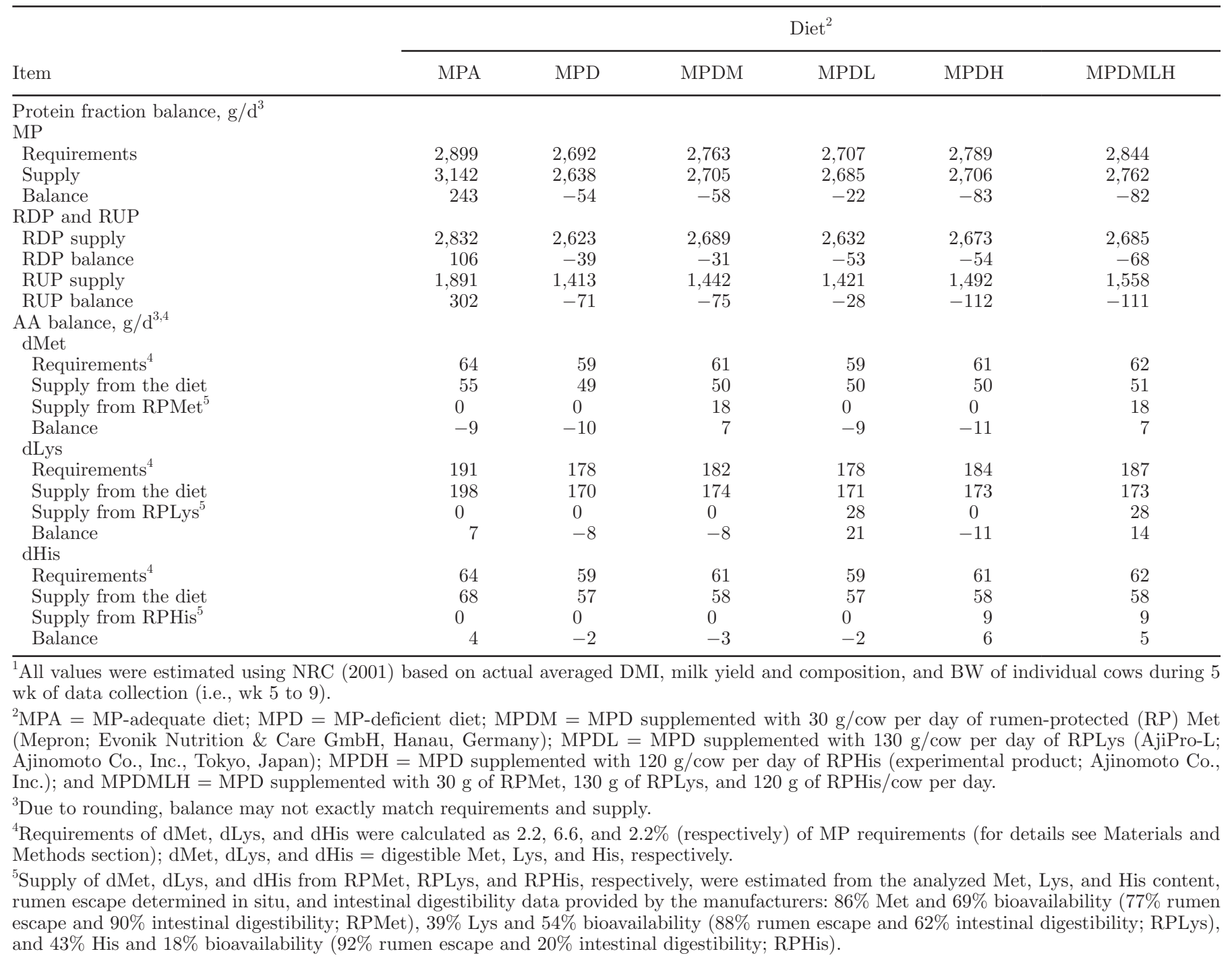


was collected into tubes without preservative during wk 5 and 6 of the experimental period and stored at $-20^{\circ} \mathrm{C}$ until analyzed for fatty acid composition as described by Rico and Harvatine (2013).

\section{Statistical Analysis}

All data were analyzed using SAS software (version 9.4, 2013; SAS Institute Inc., Cary, NC). Outliers were removed with the REG procedure of SAS based on an absolute studentized residual value $>3$. Data were assessed for normality using the UNIVARIATE procedure of SAS and log-transformed when the null hypothesis of normality was rejected $(P<0.05$ and small Shapiro-Wilk $W$ statistic). All data were analyzed using the MIXED procedure of SAS. Dry matter intake, milk yield, calculated feed efficiency (individual cow milk yield $\div$ individual DMI), and BW data (i.e., experimental wk 3 to 7 ) were averaged per week and analyzed with week as repeated measure assuming an $\operatorname{AR}(1)$ covariance structure. The statistical model included phase, week, treatment, treatment $\times$ phase and treatment $\times$ week interactions, and the covariate term. Block and block $\times$ treatment were assumed random effects, whereas all others (i.e., phase, treatment, week, phase $\times$ treatment, and week $\times$ treatment) were assumed fixed. Milk composition and all other data (i.e., BW change, milk $\mathrm{N}$ efficiency, plasma AA and metabolites and hormones, and milk fatty acids) were analyzed with the same model, excluding week and treatment $\times$ week interaction. Five pre-planned contrasts were used to analyze treatment effects as follows: $\mathrm{MP}=\mathrm{MPD}$ versus MPA; Met $=\mathrm{MPDM}$ versus MPD; Lys $=$ MPDL versus MPD; His $=\mathrm{MPDH}$ versus MPD; and MLH = MPDMLH versus MPD. Additionally, when the main effect of treatment was significant, means were separated by pairwise $t$-test (pdiff option of PROC MIXED) to compare the RP AA-supplemented diets with the MPA diet. The results of this analysis are not published in tables, but for the production data are discussed in the Results and Discussion sections. All data are presented as least squares means or covariateadjusted least squares means. Statistical differences were declared significant at $P \leq 0.05$ and tendencies at $0.05<P \leq 0.10$.

\section{RESULTS}

In both phases of the experiment, the MPD diets were formulated to contain less CP compared with the MPA diets by including more ground corn and less SoyPLUS (Table 1). The MPD diets had similar fiber fractions (i.e., $\mathrm{NDF}$ and $\mathrm{ADF}$ ) and $\mathrm{NE}_{\mathrm{L}}$ and higher $\mathrm{NFC}$ and starch concentrations compared with the MPA diets. The $\mathrm{NE}_{\mathrm{L}}$ balance (NRC, 2001) of the cows was positive in both phases with all diets.

As a result of similar predicted protein fractions and AA balance (based on NRC, 2001) between phase 1 and 2 of the experiment, the average data are reported in Table 2. As expected, the MPA diet met or exceeded the MP, RDP, and RUP requirements of the cows. Due to higher than expected DMI, the MP and AA status of cows fed the MPD diets was less negative than planned. Consequently, RP AA supplementation of the MPD diets provided digestible AA, and particularly dLys, in excess of the assumed requirements. The predicted MP, RDP, and RUP balances were negative for all MPD diets. According to Schwab et al. (2005), the MPA diet was $14 \%$ dMet deficient and met the dLys requirements. The diets supplemented with RPMet (MPDM and MPDMLH) and RPLys (MPDL and MPDMLH) exceeded the estimated requirements of dMet and dLys, respectively. The MPD diets that were not supplemented with RPMet were 15 to $18 \%$ dMet deficient (MPD, MPDL and MPDH); the diets that were not supplemented with RPLys were 4 to $6 \%$ dLys deficient (MPD, MPDM and MPDH). According to Lee et al. (2012a), the MPA diet and the RPHis-supplemented diets (MPDH and MPDMLH) met the assumed dHis requirements, whereas all other diets were $3 \%$ (MPD and MPDL) and 5\% (MPDM) deficient in dHis.

Dry matter intake was or tended to be decreased by MPD compared with MPA $(P=0.01), \mathrm{MPDH}(P=$ $0.09)$, and MPDMLH $(P=0.08$; Table 3$)$. Dry matter intake tended also to be lower for $\operatorname{MPDM}(P=$ $0.08)$ and MPDL $(P=0.07)$, compared with MPA. Cows fed the RPHis-supplemented diets (MPDH and MPDMLH) had DMI not different from the MPA cows $(P \geq 0.23)$. Milk and lactose yields and feed efficiency were decreased $(P \leq 0.04)$ by all MPD diets (including MPDMLH) compared with MPA. Milk fat concentration tended to be increased $(P=0.09)$ for MPDMLH compared with MPD and was not different $(P=0.53)$ for MPDM, MPDL, MPDH, and MPDMLH, compared with MPA. Milk true protein concentration was increased $(P \leq 0.04)$ with MPDL, MPDH, and MPDMLH versus MPD. Milk true protein content was also higher or tended to be higher for MPDL and MPDMLH ( $P$ $\leq 0.02)$, and MPDH $(P=0.06)$ compared with MPA. Concentration of MUN was decreased $(P<0.01)$ by all MPD diets (including MPDMLH) versus MPA. Milk urea $\mathrm{N}$ tended to be higher $(P=0.07)$ for MPDL versus MPD. Milk fat, protein, and ECM yields, ECM feed efficiency, and milk $\mathrm{NE}_{\mathrm{L}}$ were decreased $(P \leq 0.05)$ by MPD, MPDM, MPDL, and MPDH compared with MPA, and were increased $(P \leq 0.05)$ by MPDMLH 
Table 3. Effects of MP supply and rumen-protected (RP) AA supplementation on DMI, milk production and composition, and BW in dairy cows

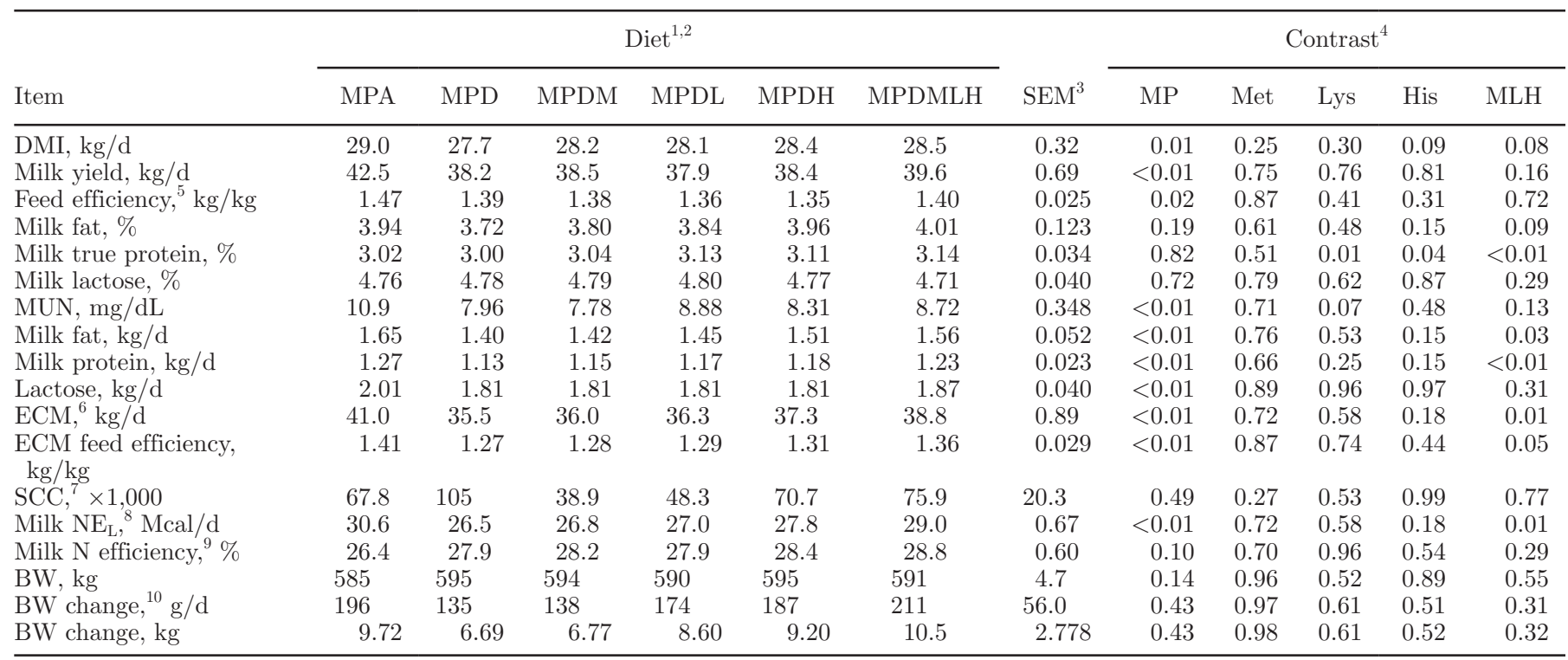

${ }^{1} \mathrm{MPA}=\mathrm{MP}$-adequate diet; MPD = MP-deficient diet; MPDM = MPD supplemented with RPMet (Mepron; Evonik Nutrition \& Care GmbH Hanau, Germany); MPDL = MPD supplemented with RPLys (AjiPro-L; Ajinomoto Co., Inc., Tokyo, Japan); MPDH = MPD supplemented with RPHis (Ajinomoto Co., Inc.); MPDMLH = MPD supplemented with RPMet, RPLys, and RPHis.

${ }^{2}$ Covariate-adjusted LSM for DMI, milk yield, and milk composition and yields.

${ }^{3}$ Largest SEM published in table. DMI, $\mathrm{n}=360$; milk yield and feed efficiency, $\mathrm{n}=359 ; \mathrm{BW}, \mathrm{n}=321 ; \mathrm{BW}$ change, $\mathrm{n}=70 ;$ milk composition data, $\mathrm{n}=70$ to 72 ; milk $\mathrm{N}$ efficiency, $\mathrm{n}=72$ ( $\mathrm{n}$ represents number of observations used in the statistical analysis).

${ }^{4} \mathrm{MP}=\mathrm{MPD}$ vs. MPA; Met $=$ MPDM vs. MPD; Lys $=$ MPDL vs. MPD; His $=$ MPDH vs. MPD; and MLH = MPDMLH vs. MPD.

${ }^{5}$ Milk yield/DMI.

${ }^{6}$ Energy-corrected milk $(\mathrm{kg} / \mathrm{d})=\mathrm{kg}$ of milk $\times[(38.3 \times \%$ fat $\times 10+24.2 \times \%$ true protein $\times 10+16.54 \times \%$ lactose $\times 10+20.7) \div 3,140]$ (Sjaunja et al., 1990).

${ }^{7}$ Statistical analysis was performed on log-transformed data. Outliers were removed based on an absolute studentized residual value $>3$ (REG procedure of SAS, SAS Institute Inc., Cary, NC).

${ }^{8} \mathrm{Milk} \mathrm{NE}_{\mathrm{L}}(\mathrm{Mcal} / \mathrm{d})=\mathrm{kg}$ of milk $\times(0.0929 \times \%$ fat $+0.0563 \times \%$ true protein $+0.0395 \times \%$ lactose $)(\mathrm{NRC}, 2001)$.

${ }^{9}$ Milk $\mathrm{N}$ yield/N intake $\times 100$.

${ }^{10} \mathrm{BW}$ change, $\mathrm{g} / \mathrm{d}=$ (average BW during the last week of experiment - average BW during the second week of covariate period $) \div$ days of experiment (49 d for most cows).

versus MPD. Milk fat and protein yields and ECM feed efficiency were not different $(P \geq 0.22)$, whereas ECM yield and milk $\mathrm{NE}_{\mathrm{L}}$ tended to be decreased $(P=0.09)$ by MPDMLH versus MPA. Milk N efficiency tended or was increased by MPD and MPDL $(P \leq 0.10)$, and MPDM, MPDH, and MPDMLH $(P \leq 0.04)$, compared with MPA. Milk lactose concentration, SCC, and BW and BW change of the cows were not affected by treatments $(P \geq 0.26)$.

Concentrations of plasma AA are presented in Table 4. Plasma Ala was increased by MPD $(P=0.05)$ compared with MPA. A treatment $\times$ phase interaction was found for plasma Ala $(P=0.03)$, but examination of the data showed similar trends for both experimental phases. Plasma concentrations of Arg, Ile, Leu, Phe, and Val, and total EAA were decreased $(P<0.01)$ by MPD compared with MPA. Relative to MPA, plasma Asn and Gln were or tended to be lower $(P=0.03$ and 0.06 , respectively) with MPDM. Plasma Asn concentration tended to decrease $(P=0.09)$ and Asp was decreased $(P=0.02)$ with MPDL versus MPA. Concentrations of Gly and Ser tended to be higher $(P=0.07$ and 0.10 , respectively) for MPD versus MPA. Concentration of Glu tended to be higher $(P=0.09)$ for MPDH versus MPA. Plasma Ser was decreased $(P=0.05)$ and Ala and total NEAA tended to be decreased $(P=0.09$ and 0.06 , respectively) by MPDM compared with MPD. Concentrations of His were lower $(P<0.01)$ for MPD, MPDM, and MPDL compared with MPA, and were increased $(P<0.01)$ by MPDH and MPDMLH versus MPD. Plasma Lys was or tended to be decreased by MPD and MPDM $(P \leq 0.04)$, and MPDH $(P=0.08)$ than MPA. The MPDL and MPDMLH increased plasma Lys levels $(P \leq 0.03)$ compared with MPD. Concentration of Met 
Table 4. Effects of MP supply and rumen-protected (RP) AA supplementation on plasma AA concentrations $(\mu M)$ in dairy cows

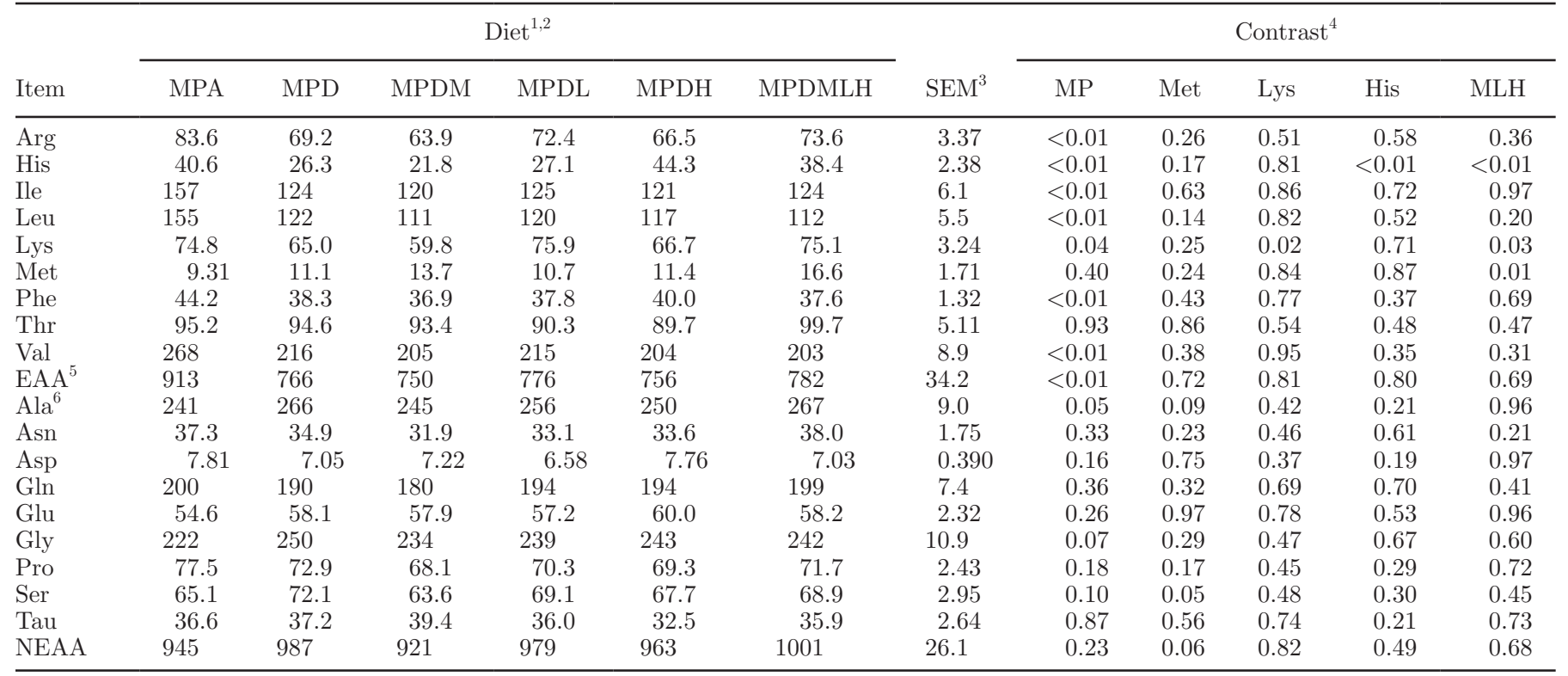

${ }^{1} \mathrm{MPA}=\mathrm{MP}$-adequate diet; MPD = MP-deficient diet; MPDM = MPD supplemented with RPMet (Mepron; Evonik Nutrition \& Care GmbH, Hanau, Germany); MPDL = MPD supplemented with RPLys (AjiPro-L; Ajinomoto Co., Inc., Tokyo, Japan); MPDH = MPD supplemented with RPHis (Ajinomoto Co., Inc.); MPDMLH = MPD supplemented with RPMet, RPLys, and RPHis.

${ }^{2}$ Covariate-adjusted LSM.

${ }^{3}$ Largest SEM published in table, $\mathrm{n}=68$ to 72 ( $\mathrm{n}$ represents number of observations used in the statistical analysis).

${ }^{4} \mathrm{MP}=\mathrm{MPD}$ vs. MPA; Met $=$ MPDM vs. MPD; Lys $=$ MPDL vs. MPD; His = MPDH vs. MPD; and MLH = MPDMLH vs. MPD.

${ }^{5}$ Sum of all EAA (without Trp).

${ }^{6}$ Treatment $\times$ experimental phase interaction $(P=0.03)$.

was increased $(P=0.01)$ by MPDMLH compared with MPD, and tended $(P=0.06)$ or was $(P<0.01)$ higher, respectively, for MPDM and MPDMLH compared with MPA. Concentrations of Pro, Tau, and Thr were not affected by treatments.

Blood hemoglobin concentration was decreased $(P$ $\leq 0.03$ ) by MPD, MPDM, and MPDL compared with MPA (Table 5). Blood hemoglobin levels were not dif- ferent for cows receiving the MPDH and MPDMLH diets, compared with MPA $(P \geq 0.11)$. Plasma urea $\mathrm{N}$ was decreased $(P<0.01)$ with all MPD diets versus MPA. Glucose concentration was increased by MPDL $(P=0.03)$ and MPDMLH $(P=0.02)$ compared with MPD. Plasma insulin and creatinine were not affected by treatment. Concentration of ghrelin was numerically higher $(P=0.14)$ with MPD compared with MPA.

Table 5. Effects of MP supply and rumen-protected (RP) AA supplementation on blood plasma metabolites and hormones in dairy cows

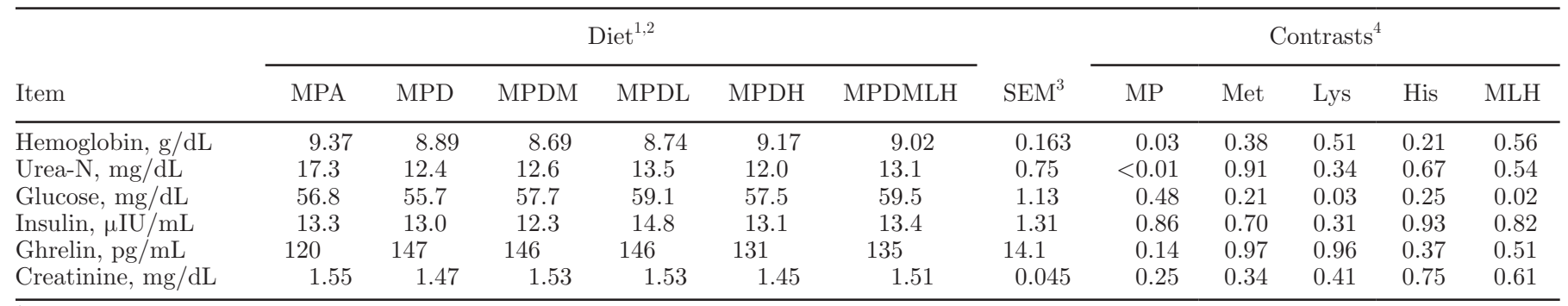

${ }^{1} \mathrm{MPA}=\mathrm{MP}$-adequate diet; MPD = MP-deficient diet; MPDM = MPD supplemented with RPMet (Mepron; Evonik Nutrition \& Care GmbH, Hanau, Germany); MPDL = MPD supplemented with RPLys (AjiPro-L; Ajinomoto Co., Inc., Tokyo, Japan); MPDH = MPD supplemented with RPHis (Ajinomoto Co., Inc.); MPDMLH = MPD supplemented with RPMet, RPLys, and RPHis.

${ }^{2}$ Covariate-adjusted LSM.

${ }^{3}$ Largest SEM published in table, $\mathrm{n}=69$ to 72 ( $\mathrm{n}$ represents number of observations used in the statistical analysis).

${ }^{4} \mathrm{MP}=\mathrm{MPD}$ vs. MPA; Met $=$ MPDM vs. MPD; Lys $=$ MPDL vs. MPD; His $=$ MPDH vs. MPD; and MLH $=$ MPDMLH vs. MPD. 
Table 6. Effects of MP supply and rumen-protected (RP) AA supplementation on milk fatty acid composition (g/100 g of total fatty acids) in dairy cows

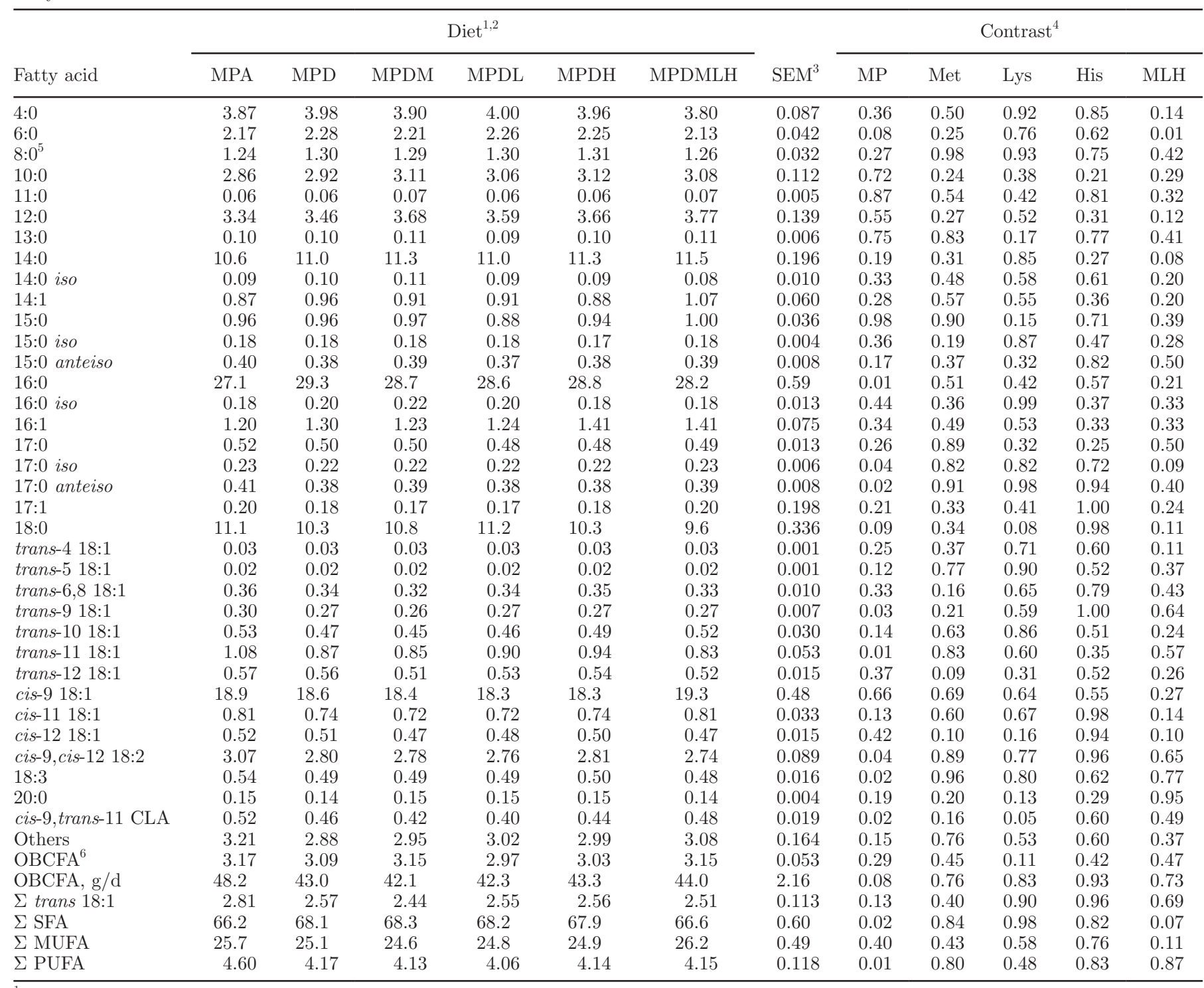

${ }^{1} \mathrm{MPA}=\mathrm{MP}$-adequate diet; MPD = MP-deficient diet; MPDM = MPD supplemented with RPMet (Mepron; Evonik Nutrition \& Care GmbH Hanau, Germany); MPDL = MPD supplemented with RPLys (AjiPro-L; Ajinomoto Co., Inc., Tokyo, Japan); MPDH = MPD supplemented with RPHis (Ajinomoto Co., Inc.); MPDMLH = MPD supplemented with RPMet, RPLys, and RPHis.

${ }^{2}$ Covariate-adjusted LSM.

${ }^{3}$ Largest SEM published in table, $\mathrm{n}=69$ to 72 ( $\mathrm{n}$ represents number of observations used in the statistical analysis).

${ }^{4} \mathrm{MP}=\mathrm{MPD}$ vs. MPA; Met $=$ MPDM vs. MPD; Lys $=$ MPDL vs. MPD; His = MPDH vs. MPD; and MLH $=$ MPDMLH vs. MPD.

${ }^{5}$ Treatment $\times$ experimental phase interaction $(P=0.01)$.

${ }^{6}$ Odd- and branched-chain fatty acids $=$ sum of odd- $(15: 0,17: 0,17: 1)$ and branched-chain $(14: 0$ iso, 15:0 iso, 16:0 iso, 17:0 iso, 15:0 anteiso, 17:0 anteiso) fatty acids.

Overall, the MPD diet increased the concentration of total SFA (mainly due to an increase in 16:0) and decreased total PUFA (mainly due to a decrease in 18:2 and 18:3), trans-9 and trans-11 18:1, and cis-9,trans-11 CLA in milk fat compared with MPA $(P \leq 0.04$; Table $6)$. Concentrations of 17:0 iso and 17:0 anteiso were de- creased $(P \leq 0.04)$ and yield of milk odd- and branchedchain fatty acids (OBCFA) tended to be decreased $(P$ $=0.08$ ) by MPD versus MPA. Concentrations of 6:0 was decreased $(P=0.01)$ and total SFA tended to be decreased $(P=0.07)$ by MPDMLH versus MPD. A treatment $\times$ phase interaction was observed for 8:0 $(P$ 
$=0.01$, but analysis of the data by phase revealed similar trends between phase 1 and 2 of the experiment.

\section{DISCUSSION}

The decreased DMI with the MPD diet compared with MPA was one of the main effects observed in this experiment. This result is in agreement with previous studies (Haque et al., 2012; Lee et al., 2012a) and meta-analyses (Huhtanen and Hetta, 2012; Owens and Sapienza, 2014) that have shown a positive relation between dietary protein concentration and DMI. However, this effect has not always been observed with levels of dietary protein similar to (Lee et al., 2012c; Giallongo et al., 2015a) or even lower than (Colmenero and Broderick, 2006) the current experiment. The higher forage inclusion in the present, Haque et al. (2012), and Lee et al. (2012a) experiments (from 63 to $71 \%$ of DM) compared with the above-mentioned studies (from 50 to $52 \%$ of $\mathrm{DM}$ ) may have exacerbated the negative effects of the lower RDP supply (ammonia, AA, and peptides) on rumen fiber digestibility (Allen, 2000; Bach et al., 2005) with the MPD diets, thus leading to reduced DMI. Another important factor that may have contributed to the decrease in DMI with the MPD diet in the current study is the lower supply of RUP, particularly the postruminal effects of EAA supply on DMI (Lee et al., 2012a).

Supplementation of the MPD diet with RPMet and RPLys did not affect DMI, similar to our previous data (Giallongo et al., 2015a; Lee et al., 2015a) and other studies (Robinson et al., 1998; Benefield et al., 2009). However, contrasting responses in DMI (i.e., increase or decrease) to RPMet supplementation have been reported (Patton, 2010; Zanton et al., 2014). These diverse results could be due to the different sources of RPMet (Zanton et al., 2014); level of Met deficiency/ adequacy, presence of co-limiting AA, or both (Meijer et al., 1993; Patton, 2010); supplementation of Met in excess of cow requirements (Robinson et al., 2000); and a less likely suggested palatability effect (Benefield et al., 2009).

In the current study, supplementation of the MPA diet with RPHis, alone or in combination with RPMet and RPLys, tended to increase DMI to levels not different from MPA. Similar results were observed in 2 previous experiments (Lee et al., 2012a; Giallongo et al., 2015a) in which RPHis was added to MP-deficient diets balanced for Met/Lys or Met, respectively. Our findings are also in line with the outcomes of a recent meta-analysis by Patton et al. (2015) evaluating the individual effects of Met, Lys, and His. A positive effect of His on feed intake have also been reported in studies with lactating cows infused postruminally with
His (Vanhatalo et al., 1999; Ouellet et al., 2014) and in various nonruminant animals (e.g., rats and pigs) fed increasing levels of dietary His (Shin et al., 1991; see discussions in Giallongo et al., 2015a).

The reduced milk and milk component (i.e., fat, protein, lactose) yields observed with the MPD diet, resulting in lower feed and ECM feed efficiencies, are in accordance with previous studies (Broderick, 2003; Haque et al., 2012; Lee et al., 2012a). These negative effects of reducing dietary protein on productivity have been shown to be related to decreased $\mathrm{DMI}, \mathrm{NE}_{\mathrm{L}}$, and protein fraction (RUP and RDP) intakes, and supply of MP and digestible AA (particularly Met, Lys, and His; Doepel et al., 2004; Thomas, 2004; Hristov et al., 2005). Individual supplementation of the MPD diet with RPMet, RPLys, and RPHis did not affect milk yield. Similar results were reported for Met (Patton, 2010; Zanton et al., 2014) and Lys (Robinson et al., 2000), whereas a meta-analysis by Patton et al. (2015) showed a positive effect of His on milk yield, partially through improved DMI, and similar trends were observed by Lee et al. (2012a) and Giallongo et al. (2015a).

In the present study, addition of all $3 \mathrm{RP} \mathrm{AA}$ to the MPD diet numerically increased milk yield, but at levels still below those of MPA. This result can be explained in part by the trend for increased DMI (due to RPHis), and in part by the positive independent and additive effects of the 3 RP AA on MPY (Lemosquet et al., 2009; Doepel and Lapierre, 2010; Arriola Apelo et al., 2014b). Positive responses in milk yield have been observed with supplementation of the same combination of 3 EAA (Kim et al., 2000; Lee et al., 2012a), and generally no effect of adding Met + Lys (Sinclair et al., 2014; Patton et al., 2015), although Robinson et al. (2000) reported increased milk yield with Met + Lys combinations. In line with previous observations (Lee et al., 2012a,c; Giallongo et al., 2015a), the NRC (2001) model underpredicted MP-allowable milk yield of cows fed the MPD and MPD diets supplemented with RP AA (i.e., MPDM, MPDL, MPDH, and MPDMLH) by 2.4 and on average $4.0 \mathrm{~kg} / \mathrm{d}$, respectively; and overestimated milk yield of cows fed the MPA diet by 5.4 $\mathrm{kg} / \mathrm{d}$ (see discussions in Lee et al., 2012c; Giallongo et al., 2015a).

In the current study, milk fat concentration was numerically decreased with the MPD diet, probably due to lower RDP supply, fiber digestibility, and acetic and butyric acid production (Linn, 1988) compared with the MPA diet. In agreement, Colmenero and Broderick (2006) reported a decrease in milk fat content with decreasing dietary protein, which was related to lower fiber digestibility, ammonia, and rumen branched-chain VFA and acetate concentration. However, in other experiments (Haque et al., 2012; Lee et al., 2012a), milk 
fat concentration was not affected by the MP level of the diet.

Individual supplementation (or combinations) of Met and Lys did not affect milk fat concentration in the current experiment, consistent with some studies and meta-analyses (Lee et al., 2012c; Patton et al., 2015). However, other studies reported increased milk fat content with Met and with Met + Lys supplementation (Watanabe et al., 2006; Zanton et al., 2014), which has been mainly attributed to the effect of Met on methyl groups supply and choline synthesis (Pinotti et al., 2002). Previously, we observed a trend for lower milk fat content (due to the numerical increased milk yield; Giallongo et al., 2015a) and no effect (Lee et al., 2012a) of RPHis. Others (Fraser et al., 1991; Kim et al., 1999; Vanhatalo et al., 1999) reported a negative effect of His infusion on milk fat concentration, which seemed to be linked to a dilution effect caused by a concurrent increase in milk yield. Addition of the $3 \mathrm{RP}$ AA to MPD tended to increase milk fat concentration in the present study. This effect can be attributed, at least in part, to the increased supply of fat (i.e., RP fat) from the RPLys $(+64 \mathrm{~g})$ and RPHis $(+67 \mathrm{~g})$ products, as increases in milk fat content have been reported with similar fat sources (Onetti and Grummer, 2004; Rabiee et al., 2012).

Addition of RPMet to the MPD diet did not affect milk protein concentration, in line with our previous (Giallongo et al., 2015a) and other (Arriola Apelo et al., 2014a) experiments. Others, however, reported increased milk protein content with RPMet supplementation (Kröber et al., 2000; Ordway et al., 2009). In these mentioned studies, the supplies and balances of other key AA (e.g., Lys, His) limiting milk protein synthesis may have played an important role in the observed inconsistent response to the addition of RPMet in MPdeficient diets (Doepel and Lapierre, 2010; Hristov and Giallongo, 2014). Individual supplementation of RPLys and RPHis, or in combinations with RPMet, increased milk protein content in the current study. These results are in agreement with some previous studies that have showed positive responses in milk protein concentration to supplementation of Lys (Schwab et al., 1992; Lapierre et al., 2009) and His (Huhtanen et al., 2002; Weekes et al., 2006) in diets deficient in these AA.

In the present experiment, the increase in milk protein and fat content with the combinations of the $3 \mathrm{RP}$ AA, together with the numerically higher milk yield, led to an increase in milk fat yield and MPY to levels not different from MPA. As a result, ECM yield was also increased by the addition of the $3 \mathrm{RP}$ AA to the MPD diet, but at levels still below those of MPA. The proportionally higher increase in ECM compared with
DMI on the other hand led to increased ECM feed efficiency of cows fed the $3 \mathrm{RP}$ AA-supplemented diet.

Cows fed the MPD diets had lower concentrations of milk and plasma urea $\mathrm{N}$ and higher milk $\mathrm{N}$ efficiency compared with cows fed MPA, indicating higher efficiency of dietary AA utilization for milk protein synthesis (Lee et al., 2015a). These observed effects seems to be due to a combination of lower DM and protein intakes, negative RDP and RUP balances, and higher starch content with MPD diets versus MPA (Patton et al., 2014). These results are in line with those observed in other studies (Colmenero and Broderick, 2006; Lee et al., 2012a) and have been consistently shown to be linked to reduced urinary $\mathrm{N}$ excretion and ammonia emission from dairy farms (Castillo et al., 2000; Lee et al., 2012b). The trend for increased MUN with addition of RPLys to the MPD diet suggests increased Lys catabolism probably because it was in excess with respect to other EAA (e.g., Met, His) for milk protein synthesis (Doepel et al., 2004). It is also worth noting that whereas milk $\mathrm{N}$ efficiency tended to be increased by MPD and MPDL (for the above mentioned reasons), it was significantly improved by MPDM, MPDH, and MPDMLH compared with MPA. These results indicate that supplementing the MPD diet with the EAA Met and His was effective to further improve the efficiency of MP utilization for milk protein synthesis (Haque et al., 2012).

Body weight change of the cows was not affected by treatment in the current experiment. In contrast, in our previous study (Giallongo et al., 2015a) cows fed a $5 \%$ MP-deficient diet were gaining less BW compared with those supplemented with urea and RP AA or fed a MP-adequate diet. However, in the current experiment the MP and AA deficiencies resulted in decreased yields of milk and milk components, whereas in Giallongo et al. (2015a) the deficiencies were only manifested in decreased BW gain (i.e., no effect on milk and components yields). Similar negative effects of feeding MP-deficient diets on BW change or milk production were reported in other long-term experiments (Lee et al., 2012c and Lee et al., 2011a, respectively). Dairy cows are able to mobilize body protein to counteract AA deficiencies (e.g., for milk protein synthesis), and although they may show no milk production responses they may lose BW (e.g., early lactation; van der Drift et al., 2012; Patton et al., 2014). These results highlight the importance of evaluating BW change when studying MP and AA effects.

Cows fed the MPD diets (unsupplemented with RP AA), had lower plasma concentrations of most of the EAA (Arg, His, Ile, Leu, Lys, Phe, and Val), whereas Met was not different compared with MPA (in agree- 
ment with the similar dMet balance in both diets; see Table 2), similar to the observations by Lee et al. (2012a,c) and Haque et al. (2012). Concentrations of the non-EAA plasma Gly and Ser tended to be increased by the MPD diet compared with MPA in agreement with our previous studies (Lee et al., 2012a, 2015a; Giallongo et al., 2015a). As shown by the production data in this study, in addition to the supplemented Met, Lys, and His, other EAA such as the branched-chain AA (Rulquin and Pisulewski, 2006; Haque et al., 2013) might have limited productivity (particularly MPY) of dairy cows. However, the branched-chain AA do not seem to be among the most limiting in dairy cows, and the benefit of their supplementation (i.e., milk protein synthesis) has not been consistently demonstrated (Patton et al., 2014).

Increases in plasma Met concentrations, similar to those observed for MPDMLH in the current study, have been reported with the same RPMet product (Berthiaume et al., 2006; Lee et al., 2012a; Giallongo et al., 2015a). Plasma Lys concentration was increased with addition of RPLys and similar results have been reported by others (Xu et al., 1998; Lee et al., 2012a), whereas in some studies only numerical increases in plasma Lys were observed (Swanepoel et al., 2010; Paz and Kononoff, 2014; Lee et al., 2015a). The difference among studies using RP AA may be in part due to lower than calculated AA bioavailability (Owens and Sapienza, 2014).

Supplementation of MPD with RPHis was effective to increase plasma His to the level of the MPA diet. In contrast to the current and previous long-term experiments (Lee et al., 2012a,c), plasma His levels were not decreased by MP-deficient diets in a short-term Latin square (Lee et al., 2015a) and in a long-term (see discussion by Giallongo et al., 2015a) experiments. In Giallongo et al. (2015a), concentrations of plasma and muscle His-dipeptides (i.e., the endogenous His pools: carnosine and anserine) were also not affected, but changes in blood hemoglobin were not assessed. Hemoglobin is another endogenous reserve of His (which contains about 8\% His; Dayhoff, 1969) that can provide His to the cow during short periods of His deficiency (Hristov and Giallongo, 2014). In this study, cows fed the MP-His-deficient diets (MPD, MPDM, MPDL) had, on average, a $6 \%$ decrease in blood hemoglobin concentrations compared with those fed the MPA diet, suggesting a supply of about $16.7 \mathrm{~g}$ of His from this endogenous depot during the 6-wk experimental period. Supply of His from hemoglobin was estimated from the analyzed blood hemoglobin concentration, and assuming $8 \%$ His content for hemoglobin and a blood volume of $7.5 \%$ of BW (Dayhoff, 1969). Cows supplemented with RPHis had hemoglobin levels not different from MPA cows, but still numerically lower (particularly for MPDMLH). Short-term studies with dairy cows infused abomasally with decreasing levels of His have also shown linear decreases in plasma His and carnosine, and trends for lower blood hemoglobin and muscle carnosine concentrations (Lapierre et al., 2014; Ouellet et al., 2014). Similarly, studies with cockerels (Amend et al., 1979) and rats (Clemens et al., 1984) fed His-deficient diets have also reported decreases in blood hemoglobin and muscle carnosine, and no changes in muscle anserine concentrations. Cho et al. (1984) also observed a decline in plasma His and hemoglobin concentrations together with increased iron levels, and negative $\mathrm{N}$ balance, in adult men consuming a low His diet for 8 wk. Thus, based on existing data, further studies are needed to determine for how long and to what extent blood hemoglobin (together with plasma and muscle His-dipeptides) can provide His to lactating dairy cows fed His-deficient diets.

Plasma glucose and insulin concentration were not affected by RPMet supplementation, similar to our previous (Giallongo et al., 2015a) and other (Berthiaume et al., 2006; Preynat et al., 2009) findings, although increases in both plasma variables have also been reported (Kröber et al., 2000; Berthiaume et al., 2001). Addition of RPLys increased plasma glucose concentration in contrast with previous studies that reported no effect of RPLys (Misciatteilli et al., 2003; Socha et al., 2005) or postruminal Lys supplementation (Schwab et al., 1992; Varvikko et al., 1999) on plasma glucose. Supplementation of RPHis did not influence plasma glucose levels (and insulin; Weekes et al., 2006), in line with data from several postruminal His infusion studies (Korhonen et al., 2000; Cant et al., 2001; Huhtanen et al., 2002). The lack of effect of RPLys and RPHis on plasma insulin levels is consistent with the insulin responses to infusion of Lys and His in sheep (Kuhara et al., 1991). As discussed by Giallongo et al. (2015a), factors such as dietary starch and protein (Kröber et al., 2000; Cantalapiedra-Hijar et al., 2014) and sources and dosages of supplemented RP AA (Blum et al., 1999; Ranawana and Kaur, 2013) may be responsible for the observed discrepancies among experiments in plasma glucose and insulin responses to AA supplementation.

Ghrelin concentrations were not affected by the MPD diets in the current study. However, the numerical increase with the MPD diets, particularly MPD, MPDM, and MPDL, is consistent with the observed lower DMI of cows on these diets; it has been shown that plasma ghrelin concentrations increase as a result of prolonged, moderate (steers, Wertz-Lutz et al., 2008) and transient (sheep, Sugino et al., 2002; dairy cows, Bradford and Allen, 2008) DMI restriction. The lowest ghrelin concentration for cows fed MPA is also in agree- 
ment with studies which have shown that ghrelin levels are suppressed by food ingestion (Miura et al., 2004; Cummings, 2006; Roche et al., 2007) and that dietary protein consumption, compared with other macronutrients, can induce prolonged postprandial ghrelin suppression in humans, and ruminant and nonruminant animals (Vallejo-Cremades et al., 2004; Foster-Schubert et al., 2008; Takahashi et al., 2012). However, some studies have also shown inconsistent effects of various nutrients (i.e., carbohydrate, protein, fat) on plasma ghrelin concentrations, which may be attributable to different forms of ghrelin studied (i.e., active versus total), genetic factors, diets used, and study design (Karhunen et al., 2008; Sartin et al., 2011; Foote et al., 2014).

In the present study, plasma concentration of creatinine was not influenced by treatment. This observation is in line with the similar BW (and positive BW gain) of the cows on all treatments, because plasma creatinine concentration is known to be directly related to BW, muscle mass, and muscle proteolysis (Perrone et al., 1992; Shahzad et al., 2014).

The main changes in milk fatty acid profile in the current study were the slightly increased concentrations of total SFA (mainly 16:0) and decreased total PUFA (mainly 18:2 and 18:3), trans-11 18:1, and CLA with the MPD diet compared with MPA. These results are explained by the lower intake of dietary C18-unsaturated fatty acids from expeller soybean meal (SoyPLUS, containing $6.5 \%$ oil on a DM basis) for MPD-fed cows. It is known that the level of intake of these fatty acids has the greatest influence on concentration of C18fatty acids and products of rumen biohydrogenation of C18-fatty acids (trans fatty acids and CLA) in milk fat (Onetti and Grummer, 2004). To a lesser extent, the lower dietary RDP concentration with the MPD diet may have also decreased rumen lipolysis and biohydrogenation of C18-fatty acids, and consequently trans-11 18:1, and CLA concentrations in milk fat (Gerson et al., 1983; Gressley and Armentano, 2007). Comparable alterations in milk fatty acid composition have been reported in cows fed diets with decreasing levels of oil from heat-treated soybean products (Peterson et al., 2002; Lee et al., 2011a; Giallongo et al., 2015b).

The yield of milk OBCFA tended to be decreased by the MPD diet versus MPA. Milk OBCFA primarily derive from rumen bacterial lipids, and have been proposed as markers of microbial protein synthesis and outflow from the rumen (and composition of rumen bacteria; Vlaeminck et al., 2006). Lee et al. (2015b), for example, observed increased yield of milk OBCFA (mainly 15:0 and 17:1), which were positively related to microbial CP outflow from the rumen in cows supplemented with a Met analog. In the present study, the lower levels of RDP with the MPD diet may have led to decreased rumen microbial synthesis of OBCFA, and hence reduced incorporation in milk fat. Indeed, Vlaeminck et al. (2015) reported a negative effect of reducing dietary $\mathrm{CP}$ and RDP on duodenal flow and milk OBCFA yield. A positive relation between dietary RDP supply and concentration of some milk OBCFA was also described by Leduc et al. (2014).

Milk fatty acid composition was generally not affected by addition of RP AA, in agreement with previous studies (Karunanandaa et al., 1994; Robinson et al., 2011). However, the observed trend for lower total SFA with the combination of the $3 \mathrm{RP}$ AA may be due to fatty acid supply from the RPLys and RPHis products. In other studies, changes in milk fatty acids were attributed to the effects of the supplemented AA on mammary gland supply of substrates (nonesterified fatty acids, triglycerides, glucose) and de novo synthesis of fatty acids (Guinard and Rulquin, 1994; Pisulewski et al., 1996; Varvikko et al., 1999), or growth of rumen microorganisms (see discussion by Giallongo et al., 2015a).

\section{CONCLUSIONS}

The results of this study showed that feeding a diet slightly deficient in MP decreased DMI, feed efficiency, and yields of milk and milk components in dairy cows. Cows fed the MPD diets had lower milk and plasma urea $\mathrm{N}$ and higher milk $\mathrm{N}$ efficiency compared with cows fed MPA. Supplementation of the MP-deficient diet with RPLys increased milk protein concentration. Addition of RPHis tended to increase DMI and increased milk protein content, and the combination of RPMet, RPLys, and RPHis further increased yields of milk fat, protein, and ECM and ECM feed efficiency. Cows fed the MPD diet had lower blood circulating levels of hemoglobin than cows fed MPA, suggesting a provision of His from this endogenous reserve. The observed DMI, milk composition, and plasma AA responses in the present study confirmed His as a limiting AA in lactating dairy cows fed a MP-deficient diet. Overall, data from this study confirm our previous findings and suggest that His has a positive effect on DMI and the combination of the 3 RP AA (Met, Lys, and His) has the potential to improve milk and milk component yields in dairy cows fed MP-deficient diets.

\section{ACKNOWLEDGMENTS}

This study was partially supported by funds from Evonik Nutrition \& Care GmbH (Hanau, Germany) and Ajinomoto Co., Inc. (Tokyo, Japan). The authors thank Evonik Nutrition \& Care $\mathrm{GmbH}$ for providing 
Mepron and for AA analyses of the feed and plasma samples, Ajinomoto Co., Inc. for providing AjiPro-L and the experimental RPHis product, West Central Cooperative (Ralston, IA) for providing SoyPLUS for the experiment, Kevin Harvatine's laboratory (The Pennsylvania State University) for assisting with the milk fatty acid analyses, and the staff of the Department of Animal Science Dairy Center (The Pennsylvania State University, University Park) for their conscientious care of the experimental cows.

\section{REFERENCES}

Allen, M. S. 2000. Effects of diet on short-term regulation of feed intake by lactating dairy cattle. J. Dairy Sci. 83:1598-1624.

Amend, J. F., D. H. Strumeyer, and H. Fisher. 1979. Effect of dietary histidine on tissue concentrations of histidine-containing dipeptides in adult cockerels. J. Nutr. 109:1779-1786.

AOAC International. 1995. Official Methods of Analysis. 16th ed. AOAC Int., Arlington, VA.

AOAC International. 2012. Official Methods of Analysis. 19th ed. AOAC Int., Arlington, VA.

Arriola Apelo, S. I., A. L. Bell, K. Estes, J. Ropelewski, M. J. de Veth, and M. D. Hanigan. 2014a. Effects of reduced dietary protein and supplemental rumen-protected essential amino acids on the nitrogen efficiency of dairy cows. J. Dairy Sci. 97:5688-5699.

Arriola Apelo, S. I., J. R. Knapp, and M. D. Hanigan. 2014b. Invited review: Current representation and future trends of predicting amino acid utilization in the lactating dairy cow. J. Dairy Sci. 97:4000-4017.

Bach, A., S. Calsamiglia, and M. D. Stern. 2005. Nitrogen metabolism in the rumen. J. Dairy Sci. 88:E9-E21.

Benefield, B. C., R. A. Patton, M. J. Stevenson, and T. R. Overton 2009. Evaluation of rumen-protected methionine sources and period length on performance of lactating dairy cows within Latin squares. J. Dairy Sci. 92:4448-4455.

Berthiaume, R., P. Dubreuil, M. Stevenson, B. W. McBride, and H. Lapierre. 2001. Intestinal disappearance and mesenteric and portal appearance of amino acids in dairy cows fed ruminally protected methionine. J. Dairy Sci. 84:194-203.

Berthiaume, R., M. C. Thivierge, R. A. Patton, P. Dubreuil, M. Stevenson, B. W. McBride, and H. Lapierre. 2006. Effect of ruminally protected methionine on splanchnic metabolism of amino acids in lactating dairy cows. J. Dairy Sci. 89:1621-1634.

Blum, J. W., R. M. Bruckmaier, and F. Jans. 1999. Rumen-protected methionine fed to dairy cows: Bioavailability and effects on plasma amino acid pattern and plasma metabolite and insulin concentrations. J. Dairy Sci. 82:1991-1998.

Bradford, B. J., and M. S. Allen. 2008. Negative energy balance increases periprandial ghrelin and growth hormone concentrations in lactating dairy cows. Domest. Anim. Endocrinol. 34:196-203.

Broderick, G. A. 2003. Effects of varying dietary protein and energy levels on the production of lactating dairy cows. J. Dairy Sci. 86:1370-1381

Cant, J. P., D. R. Trout, F. Qiao, and B. W. McBride. 2001. Milk composition responses to unilateral arterial infusion of complete and histidine-lacking amino acid mixtures to the mammary glands of cows. J. Dairy Sci. 84:1192-1200.

Cantalapiedra-Hijar, G., J. L. Peyraud, S. Lemosquet, E. Molina-Alcaide, H. Boudra, P. Nozière, and I. Ortigues-Marty. 2014. Dietary carbohydrate composition modifies the milk $\mathrm{N}$ efficiency in late lactation cows fed low crude protein diets. Animal 8:275-285.

Castillo, A. R., E. Kebreab, D. E. Beever, and J. France. 2000. A review of efficiency of nitrogen utilisation in lactating dairy cows and its relationship with environmental pollution. J. Anim. Feed Sci. 9:1-32.
Chase, L. E., R. J. Higgs, and M. E. Van Amburgh. 2012. Feeding low crude protein rations to dairy cows-What have we learned? Pages 32-42 in Proc. 23rd Ruminant Nutrition Symp. University of Florida, Gainesville, FL.

Cho, E. S., H. L. Anderson, R. L. Wixom, K. C. Hanson, and G. F. Krause. 1984. Long-term effects of low histidine intake on men. J. Nutr. 114:369-384.

Clemens, R. A., J. D. Kopple, and M. E. Swendseid. 1984. Metabolic effects of histidine-deficient diets fed to growing rats by gastric tube. J. Nutr. 114:2138-2146.

Colmenero, J. J. O., and G. A. Broderick. 2006. Effect of dietary crude protein concentration on milk production and nitrogen utilization in lactating dairy cows. J. Dairy Sci. 89:1704-1712.

Cummings, D. E. 2006. Ghrelin and the short- and long-term regulation of appetite and body weight. Physiol. Behav. 89:71-84.

Dayhoff, M. O. 1969. Atlas of Protein Sequence and Structure. Vol 4. National Biomedical Research Foundation, Silver Spring, MD.

Doepel, L., and H. Lapierre. 2010. Changes in production and mammary metabolism of dairy cows in response to essential and nonessential amino acid infusions. J. Dairy Sci. 93:3264-3274.

Doepel, L., D. Pacheco, J. J. Kennelly, M. D. Hanigan, I. F. Lopez, and H. Lapierre. 2004. Milk protein synthesis as a function of amino acid supply. J. Dairy Sci. 87:1279-1297.

European Commission. 2009. 2009/150/EC Commission regulation laying down the methods of sampling and analysis for the official control of feed. Off. J. L54:1-130.

Foote, A. P., K. E. Hales, C. A. Lents, and H. C. Freetly. 2014. Association of circulating active and total ghrelin concentrations with dry matter intake, growth, and carcass characteristics of finishing beef cattle. J. Anim. Sci. 92:5651-5658.

Foster-Schubert, K. E., J. Overduin, C. E. Prudom, J. Liu, H. S Callahan, B. D. Gaylinn, M. O. Thorner, and D. E. Cummings. 2008. Acyl and total ghrelin are suppressed strongly by ingested proteins, weakly by lipids, and biphasically by carbohydrates. J. Clin. Endocrinol. Metab. 93:1971-1979.

Fraser, D. L., E. R. Ørskov, F. G. Whitelaw, and M. F. Franklin. 1991 Limiting amino acids in dairy cows given casein as the sole source of protein. Livest. Prod. Sci. 28:235-252.

Gerson, T., A. John, and B. R. Sinclair. 1983. The effect of dietary $\mathrm{N}$ on in vitro lipolysis and fatty acid hydrogenation in rumen digesta from sheep fed diets high in starch. J. Agric. Sci. (Camb.) 101:97-101.

Giallongo, F., A. N. Hristov, J. Oh, T. Frederick, H. Weeks, J. Werner, H. Lapierre, R. A. Patton, A. Gehman, and C. Parys. 2015a Effects of slow-release urea and rumen-protected methionine and histidine on performance of dairy cows. J. Dairy Sci. 98:3292-3308.

Giallongo, F., J. Oh, T. Frederick, B. Isenberg, D. M. Kniffen, R A. Fabin, and A. N. Hristov. 2015b. Extruded soybean meal increased feed intake and milk production in dairy cows. J. Dairy Sci. 98:6471-6485.

Gressley, T. F., and L. E. Armentano. 2007. Effects of low rumen-degradable protein or abomasal fructan infusion on diet digestibility and urinary nitrogen excretion in lactating dairy cows. J. Dairy Sci. 90:1340-1353.

Guinard, J., and H. Rulquin. 1994. Effects of graded amounts of duodenal infusions of lysine on the mammary uptake of major milk precursors in dairy cows. J. Dairy Sci. 77:3565-3576.

Haque, M. N., H. Rulquin, A. Andrade, P. Faverdin, J. L. Peyraud, and S. Lemosquet. 2012. Milk protein synthesis in response to the provision of an "ideal" amino acid profile at 2 levels of metabolizable protein supply in dairy cows. J. Dairy Sci. 95:5876-5887.

Haque, M. N., H. Rulquin, and S. Lemosquet. 2013. Milk protein responses in dairy cows to changes in postruminal supplies of arginine, isoleucine, and valine. J. Dairy Sci. 96:420-430.

Hristov, A. N., and F. Giallongo. 2014. Feeding protein to dairy cows - What should be our target? Pages 75-84 in Proc. Tri-State Dairy Nutr. Conf., Fort Wayne, IN. Ohio State Univ., Columbus.

Hristov, A. N., W. J. Price, and B. Shafii. 2005. A meta-analysis on the relationship between intake of nutrients and body weight with milk volume and milk protein yield in dairy cows. J. Dairy Sci. $88: 2860-2869$. 
Huhtanen, P., and M. Hetta. 2012. Comparison of feed intake and milk production responses in continuous and change-over design dairy cow experiments. Livest. Sci. 143:184-194.

Huhtanen, P., and A. N. Hristov. 2009. A meta-analysis of the effects of dietary protein concentration and degradability on milk protein yield and milk $\mathrm{N}$ efficiency in dairy cows. J. Dairy Sci. 92:3222-3232.

Huhtanen, P., A. Vanhatalo, and T. Varvikko. 2002. Effects of abomasal infusions of histidine, glucose, and leucine on milk production and plasma metabolites of dairy cows fed grass silage diets. J. Dairy Sci. 85:204-216.

Karhunen, L. J., K. R. Juvonen, A. Huotari, A. K. Purhonen, and K. H. Herzig. 2008. Effect of protein, fat, carbohydrate and fibre on gastrointestinal peptide release in humans. Regul. Pept. 149:70-78.

Karunanandaa, K., L. E. Goodling, G. A. Varga, L. D. Muller, W. W. McNeill, T. W. Cassidy, and T. Lykos. 1994. Supplemental dietary fat and ruminally protected amino acids for lactating Jersey cows. J. Dairy Sci. 77:3417-3425.

Kim, C.-H., J.-J. Choung, and D. G. Chamberlain. 1999. Determination of the first-limiting amino acid for milk production in dairy cows consuming a diet of grass silage and a cereal-based supplement containing feather meal. J. Sci. Food Agric. 79:1703-1708.

Kim, C.-H., J.-J. Choung, and D. G. Chamberlain. 2000. Variability in the ranking of the three most-limiting amino acids for milk protein production in dairy cows consuming grass silage and a cereal-based supplement containing feather meal. J. Sci. Food Agric. 80:1386-1392.

Korhonen, M., A. Vanhatalo, T. Varvikko, and P. Huhtanen. 2000. Responses to graded postruminal doses of histidine in dairy cows fed grass silage diets. J. Dairy Sci. 83:2596-2608.

Kröber, T. F., M. Kreuzer, M. Senn, W. Langhans, and F. Sutter. 2000. Effects of rumen-protected methionine in a low protein ration on metabolic traits and performance of early lactating cows as opposed to rations with elevated crude protein content. J. Anim. Physiol. Anim. Nutr. (Berl.) 84:148-164.

Kuhara, T., S. Ikeda, A. Ohneda, and Y. Sasaki. 1991. Effects of intravenous infusion of 17 amino acids on the secretion of $\mathrm{GH}$, glucagon, and insulin in sheep. Am. J. Physiol. 260:E21-E26.

Lapierre, H., L. Doepel, E. Milne, and G. E. Lobley. 2009. Responses in mammary and splanchnic metabolism to altered lysine supply in dairy cows. Animal 3:360-371.

Lapierre, H., D. R. Ouellet, and G. E. Lobley. 2014. Estimation of histidine requirement in lactating dairy cows. J. Dairy Sci. 97(Suppl. 1):757-758. (Abstr.)

Leduc, M., P. Y. Chouinard, R. Gervais, E. Baumann, Y. Lebeuf, and G. Tremblay. 2014. Milk fatty acid profile in cows fed red clover or alfalfa based diets differing in rumen-degradable protein supply. In 2014 ADSA-ASAS-CSAS Joint Annual Meeting.

Lee, C., F. Giallongo, A. N. Hristov, H. Lapierre, T. W. Cassidy, K. S. Heyler, G. A. Varga, and C. Parys. 2015a. Effect of dietary protein level and rumen-protected amino acid supplementation on amino acid utilization for milk protein in lactating dairy cows. J. Dairy Sci. 98:1885-1902.

Lee, C., A. N. Hristov, T. W. Cassidy, K. S. Heyler, H. Lapierre, G. A. Varga, M. J. de Veth, R. A. Patton, and C. Parys. 2012a. Rumenprotected lysine, methionine, and histidine increase milk protein yield in dairy cows fed a metabolizable protein-deficient diet. J. Dairy Sci. 95:6042-6056.

Lee, C., A. N. Hristov, C. J. Dell, G. W. Feyereisen, J. Kaye, and D. Beegle. 2012b. Effect of dietary protein concentration on ammonia and greenhouse gas emitting potential of dairy manure. J. Dairy Sci. 95:1930-1941.

Lee, C., A. N. Hristov, K. S. Heyler, T. W. Cassidy, H. Lapierre, G. A. Varga, and C. Parys. 2012c. Effects of metabolizable protein supply and amino acid supplementation on nitrogen utilization, milk production, and ammonia emissions from manure in dairy cows. J. Dairy Sci. 95:5253-5268.

Lee, C., A. N. Hristov, K. S. Heyler, T. W. Cassidy, M. Long, B. A. Corl, and S. K. R. Karnati. 2011a. Effects of dietary protein concentration and coconut oil supplementation on nitrogen utilization and production in dairy cows. J. Dairy Sci. 94:5544-5557.
Lee, C., J. Oh, A. N. Hristov, K. Harvatine, M. Vazquez-Anon, and G. I. Zanton. 2015b. Effect of 2-hydroxy-4-methylthio-butanoic acid on ruminal fermentation, digestibility, and performance of lactating dairy cows. J. Dairy Sci. 98:1234-1247.

Lemosquet, S., G. Raggio, G. E. Lobley, H. Rulquin, J. Guinard-Flament, and H. Lapierre. 2009. Whole-body glucose metabolism and mammary energetic nutrient metabolism in lactating dairy cows receiving digestive infusions of casein and propionic acid. J. Dairy Sci. 92:6068-6082.

Linn, J. G. 1988. Factors affecting the composition of milk from dairy cows. Pages 224-241 in Designing Foods: Animal Product Options in the Market Place. National Academy Press, Washington, DC.

Meijer, G. A., J. Van der Meulen, and A. M. Van Vuuren. 1993. Glutamine is a potentially limiting amino acid for milk production in dairy cows: A hypothesis. Metabolism 42:358-364.

Misciatteilli, L., V. F. Kristensen, M. Vestergaard, M. R. Weisbjerg, K. Sejrsen, and T. Hvelplund. 2003. Milk production, nutrient utilization, and endocrine responses to increased postruminal lysine and methionine supply in dairy cows. J. Dairy Sci. 86:275-286

Miura, H., N. Tsushiya, I. Sasaki, M. Kikuchi, M. Kojima, K. Kangawa, Y. Hasegawa, and Y. Ohnami. 2004. Changes in plasma ghrelin and hormone concentration in mature Holstein cows and three-month-old calves. J. Anim. Sci. 82:1329-1333.

NRC. 2001. Nutrient Requirements of Dairy Cattle. 7 th rev. ed. Natl. Acad. Sci., Washington, DC.

OECD/FAO (Food and Agriculture Organization of the United Nations. 2015. OECD-FAO Agricultural Outlook 2015. OECD Publishing, Paris, France.

Onetti, S. G., and R. R. Grummer. 2004. Response of lactating cows to three supplemental fat sources as affected by forage in the diet and stage of lactation: A meta-analysis of literature. Anim. Feed Sci. Technol. 115:65-82.

Ordway, R. S., S. E. Boucher, N. L. Whitehouse, C. G. Schwab, and B. K. Sloan. 2009. Effects of providing two forms of supplemental methionine to periparturient Holstein dairy cows on feed intake and lactational performance. J. Dairy Sci. 92:5154-5166.

Ouellet, D. R., G. E. Lobley, and H. Lapierre. 2014. Histidine requirement of dairy cows determined by the indicator amino acid oxidation (AAO) technique. J. Dairy Sci. 97(Suppl. 1):757. (Abstr.)

Owens, F. N., and D. A. Sapienza. 2014. Invited review: Applied protein nutrition of ruminants - Current status and future directions. Prof. Anim. Sci. 30:150-179.

Patton, R. A. 2010. Effect of rumen-protected methionine on feed intake, milk production, true milk protein concentration, and true milk protein yield, and the factors that influence these effects: A meta-analysis. J. Dairy Sci. 93:2105-2118.

Patton, R. A., A. N. Hristov, and H. Lapierre. 2014. Protein feeding and balancing for amino acid in lactating dairy cattle. Pages 599-621 in Veterinary Clinics of North America. R. J. Van Saun and R. A. Smith, ed. Elsevier, Philadelphia, PA.

Patton, R. A., A. N. Hristov, C. Parys, and H. Lapierre. 2015. Relationships between circulating plasma concentrations and duodenal flows of essential amino acids in lactating dairy cows. J. Dairy Sci. 98:4707-4734.

Paz, H. A., and P. J. Kononoff. 2014. Lactation responses and amino acid utilization of dairy cows fed low-fat distillers dried grains with solubles with or without rumen-protected lysine supplementation. J. Dairy Sci. 97:6519-6530.

Perrone, R. D., N. E. Madias, and A. S. Levey. 1992. Serum creatinine as an index of renal function: New insights into old concepts. Clin. Chem. 38:1933-1953.

Peterson, D. G., J. A. Kelsey, and D. E. Bauman. 2002. Analysis of variation in cis-9, trans-11 conjugated linoleic acid (CLA) in milk fat of dairy cows. J. Dairy Sci. 85:2164-2172.

Pinotti, L., A. Baldi, and V. Dell'Orto. 2002. Comparative mammalian choline metabolism with emphasis on the high-yielding dairy cow. Nutr. Res. Rev. 15:315-332.

Pisulewski, P. M., H. Rulquin, J. L. Peyraud, and R. Ve'rite'. 1996. Lactational and systemic responses of dairy cows to postruminal infusions of increasing amounts of methionine. J. Dairy Sci 79:1781-1791. 
Preynat, A., H. Lapierre, M. C. Thivierge, M. F. Palin, J. J. Matte, A. Desrochers, and C. L. Girard. 2009. Effects of supplements of folic acid, vitamin B12, and rumen-protected methionine on whole body metabolism of methionine and glucose in lactating dairy cows. J. Dairy Sci. 92:677-689.

Rabiee, A. R., K. Breinhild, W. Scott, H. M. Golder, E. Block, and I. J. Lean. 2012. Effect of fat additions to diets of dairy cattle on milk production and components: A meta-analysis and metaregression. J. Dairy Sci. 95:3225-3247.

Ranawana, V., and B. Kaur. 2013. Role of proteins in insulin secretion and glycemic control. Adv. Food Nutr. Res. 70:1-47.

Rico, D. E., and K. J. Harvatine. 2013. Induction of and recovery from milk fat depression occurs progressively in dairy cows switched between diets that differ in fiber and oil concentration. J. Dairy Sci. 96:6621-6630.

Robinson, P. H., W. Chalupa, C. J. Sniffen, W. E. Julien, H. Sato, T. Fujeda, T. Ueda, and H. Suzuki. 2000. Influence of abomasal infusion of high levels of lysine or methionine, or both, on ruminal fermentation, eating behavior, and performance of lactating dairy cows. J. Anim. Sci. 78:1067-1077.

Robinson, P. H., W. Chalupa, C. J. Sniffen, W. E. Julien, H. Sato, K. Watanabe, T. Fujieda, and H. Suzuki. 1998. Ruminally protected lysine or lysine and methionine for lactating dairy cows fed a ration designed to meet requirements for microbial and postruminal protein. J. Dairy Sci. 81:1364-1373.

Robinson, P. H., N. Swanepoel, I. Shinzato, and S. O. Juchem. 2011 Productive responses of lactating dairy cattle to supplementing high levels of ruminally protected lysine using a rumen protection technology. Anim. Feed Sci. Technol. 168:30-41.

Roche, J. R., A. J. Sheahan, L. M. Chagas, and D. P. Berry. 2007. Concentrate supplementation reduces postprandial plasma ghrelin in dairy cows: A possible neuroendocrine basis for reduced pasture intake in supplemented cows. J. Dairy Sci. 90:1354-1363.

Rulquin, H., and P. M. Pisulewski. 2006. Effects of graded levels of duodenal infusions of leucine on mammary uptake and output in lactating dairy cows. J. Dairy Res. 73:328-339.

Sartin, J. L., B. K. Whitlock, and J. A. Daniel. 2011. Neural regulation of feed intake: Modification by hormones, fasting and disease. J. Anim. Sci. 89:1991-2003.

Schwab, C. G., C. K. Bozak, N. L. Whitehouse, and M. M. Mesbah 1992. Amino acid limitation and flow to the duodenum at four stages of lactation. 1. Sequence of lysine and methionine limitation. J. Dairy Sci. 75:3486-3502.

Schwab, C. G., P. Huhtanen, C. W. Hunt, and T. Hvelplund. 2005. Nitrogen requirements of cattle. Pages 13-70 in Nitrogen and Phosphorus Nutrition of Cattle and Environment. E. Pfeffer and A. N. Hristov, ed. CAB Int., Wallingford, UK.

Shahzad, K., M. Bionaz, E. Trevisi, G. Bertoni, S. L. Rodriguez-Zas, and J. J. Loor. 2014. Integrative analyses of hepatic differentially expressed genes and blood biomarkers during the peripartal period between dairy cows overfed or restricted-fed energy prepartum. PLoS ONE 9:e99757.

Shin, I. S., F. N. Owens, J. E. Pettigrew, and J. W. Oltjen. 1991. Apportioning histidine requirements for maintenance versus growth. Nutr. Res. 11:1451-1463.

Sinclair, K. D., P. C. Garnsworthy, G. E. Mann, and L. A. Sinclair. 2014. Reducing dietary protein in dairy cow diets: Implications for nitrogen utilization, milk production, welfare and fertility. Animal $8: 262-274$

Sjaunja, L. O., L. Baevre, L. Junkkarinen, J. Pedersen, and J. Setälä. 1990. A Nordic proposal for an energy corrected milk (ECM) formula. Proc. 27th Session Int. Comm. Breeding Product. Milk Anim., Paris, France. Wageningen Acad. Publ., Wageningen, the Netherlands.

Socha, M. T., D. E. Putnam, B. D. Garthwaite, N. L. Whitehouse, N. A. Kierstead, C. G. Schwab, G. A. Ducharme, and J. C. Robert.
2005. Improving intestinal amino acid supply of pre- and postpartum dairy cows with rumen-protected methionine and lysine. J. Dairy Sci. 88:1113-1126.

Sugino, T., Y. Hasegawa, Y. Kikkawa, J. Yamaura, M. Yamagishi, Y. Kurose, M. Kojima, K. Kangawa, and Y. Terashima. 2002. A transient ghrelin surge occurs just before feeding in a scheduled meal-fed sheep. Biochem. Biophys. Res. Commun. 295:255-260.

Swanepoel, N., P. H. Robinson, and L. J. Erasmus. 2010. Amino acid needs of lactating dairy cows: Impact of feeding lysine in a ruminally protected form on productivity of lactating dairy cows. Anim. Feed Sci. Technol. 157:79-94.

Takahashi, T., Y. Kobayashi, S. Haga, Y. Ohtani, K. Sato, Y. Obara, A. Hagino, S. G. Roh, and K. Katoh. 2012. A high-protein diet induces dissociation between plasma concentrations of growth hormone and ghrelin in wethers. J. Anim. Sci. 90:4807-4813.

Thomas, C. 2004. Feed Into Milk: A New Applied Feeding System for Dairy Cows. Nottingham University Press, Nottingham, UK.

Vallejo-Cremades, M. T., L. Gómez-García, M. Chacatas-Cortesao, C. Moreno, M. Sánchez, E. De Miguel, and I. A. Gómez De Segura. 2004. Enriched protein diet-modified ghrelin expression and secretion in rats. Regul. Pept. 121:113-119.

van der Drift, S. G. A., M. Houweling, J. T. Schonewille, A. G. M. Tielens, and R. Jorritsma. 2012. Protein and fat mobilization and associations with serum $\beta$-hydroxybutyrate concentrations in dairy cows. J. Dairy Sci. 95:4911-4920.

Vanhatalo, A., P. Huhtanen, V. Toivonen, and T. Varvikko. 1999. Response of dairy cows fed grass silage diets to abomasal infusions of histidine alone or in combinations with methionine and lysine. J. Dairy Sci. 82:2674-2685.

Varvikko, T., A. Vanhatalo, T. Jalava, and P. Huhtanen. 1999. Lactation and metabolic responses to graded abomasal doses of methionine and lysine in cows fed grass silage diets. J. Dairy Sci. 82:2659-2673.

Virtanen, A. I. 1967. Chapter 10-The production of milk on proteinfree rations. Pages 185-212 in Urea as a Protein Supplement. 1st ed. M. H. Briggs, ed. Pergamon Press, Long Island City, NY.

Vlaeminck, B., V. Fievez, A. R. J. Cabrita, A. J. M. Fonseca, and R. J. Dewhurst. 2006. Factors affecting odd- and branched-chain fatty acids in milk: A review. Anim. Feed Sci. Technol. 131:389-417.

Vlaeminck, B., R. Gervais, M. M. Rahman, F. Gadeyne, M. Gorniak, M. Doreau, and V. Fievez. 2015. Postruminal synthesis modifies the odd- and branched-chain fatty acid profile from the duodenum to milk. J. Dairy Sci. 98:4829-4840.

Watanabe, K., A. H. Fredeen, P. H. Robinson, W. Chalupa, W. E. Julien, H. Sato, H. Suzuki, K. Katoh, and Y. Obara. 2006. Effects of fat coated rumen bypass lysine and methionine on performance of dairy cows fed a diet deficient in lysine and methionine. Anim. Sci. J. 77:495-502.

Weekes, T. L., P. H. Luimes, and J. P. Cant. 2006. Responses to amino acid imbalances and deficiencies in lactating dairy cows. J. Dairy Sci. 89:2177-2187.

Wertz-Lutz, A. E., J. A. Daniel, J. A. Clapper, A. Trenkle, and D. C. Beitz. 2008. Prolonged, moderate nutrient restriction in beef cattle results in persistently elevated circulating ghrelin concentrations. J. Anim. Sci. 86:564-575.

Xu, S., J. H. Harrison, W. Chalupa, C. Sniffen, W. Julien, H. Sato, T Fujieda, K. Watanabe, T. Ueda, and H. Suzuki. 1998. The effect of ruminal bypass lysine and methionine on milk yield and composition of lactating cows. J. Dairy Sci. 81:1062-1077.

Zanton, G. I., G. R. Bowman, M. Vázquez-Añón, and L. M. Rode. 2014. Meta-analysis of lactation performance in dairy cows receiving supplemental dietary methionine sources or postruminal infusion of methionine. J. Dairy Sci. 97:7085-7101. 